\title{
Entrepreneurship and the Determinants of Firm Survival within Regions: Human Capital, Growth Motivation and Locational Conditions
}

\author{
Robert Huggins - Cardiff University \\ Email: HugginsR@cardiff.ac.uk \\ Dan Prokop - Sheffield Hallam University \\ Piers Thompson - Nottingham Trent University \\ Email: piers.thompson@ntu.ac.uk
}

\begin{abstract}
Despite a growing body of research on firm survival, little is known about the factors impacting upon survival rates at a micro-spatial level. This study, therefore, analyses firm survival across local environments in the context of a peripheral region; namely, the case of Wales in the UK. It examines how theories relating to human capital, growth motivation and locational conditions may explain survival within a region. Drawing on data of survival patterns for a cohort of firms, it is found that each of the three theories at least partly explain firm survival, with it being clear that human capital relating to the experience of entrepreneurs, as well as the growth motivation of their firms resulting from the strategic choices they make, impact upon rates of survival. It is also found that the local environment contributes to the likelihood of its survival. In particular, it is found that locational factors have a potential influence on the human capital allocated to enterprise, as well as how this capital is utilised via growth motivation. This suggests that not only do locational factors contribute to differing rates of entrepreneurship, but that such factors also impact on the durability of firms over time.
\end{abstract}

Key words: entrepreneurship; firm survival; human capital; growth motivation; locational conditions; regions; localities; Wales.

JEL Codes: L26; L53; O1; R11.

Please cite this article as follows:

Huggins, R. Prokop, D. and Thompson, P. (2017) 'Entrepreneurship and the Determinants of Firm Survival within Regions: Human Capital, Growth Motivation and Locational Conditions', Entrepreneurship and Regional Development, doi: 10.1080/08985626.2016.1271830

This is an Accepted Manuscript of an article published by Taylor \& Francis in Entrepreneurship and Regional Development on $4^{\text {th }}$ January 2017, available online: http://www.tandfonline.com/10.1080/08985626.2016.1271830 


\title{
Entrepreneurship and the Determinants of Firm Survival within Regions: Human Capital, Growth Motivation and Locational Conditions
}

\begin{abstract}
Despite a growing body of research on firm survival, little is known about the factors impacting upon survival rates at a micro-spatial level. This study, therefore, analyses firm survival across local environments in the context of a peripheral region; namely, the case of Wales in the UK. It examines how theories relating to human capital, growth motivation and locational conditions may explain survival within a region. Drawing on data of survival patterns for a cohort of firms, it is found that each of the three theories at least partly explain firm survival, with it being clear that human capital relating to the experience of entrepreneurs, as well as the growth motivation of their firms resulting from the strategic choices they make, impact upon rates of survival. It is also found that the local environment contributes to the likelihood of its survival. In particular, it is found that locational factors have a potential influence on the human capital allocated to enterprise, as well as how this capital is utilised via growth motivation. This suggests that not only do locational factors contribute to differing rates of entrepreneurship, but that such factors also impact on the durability of firms over time.
\end{abstract}

Key words: entrepreneurship; firm survival; human capital; growth motivation; locational conditions; regions; localities; Wales.

JEL Codes: L26; L53; O1; R11.

\section{Introduction}

Existing studies of firm survival have suggested that a whole host of factors may influence the extent to which entrepreneurs are able to establish viable business concerns. The most prominent underlying influences concern the human capital of entrepreneurs (Gimmon and Levie 2010; Rauch and Rijsdijk 2013), the growth motivation of entrepreneurs in terms of the development of their firms (North, Leigh, and Smallbone 1992), as well as external environmental factors relating to the spatial location of the firms and the industrial structure within which firms operate (Renski 2011; Stephan 2011; Pe'er, Vertinsky, and Keil 2016). Most studies have analysed survival within or across nations and regions, and have generally indicated that the role of entrepreneurial capacity and orientation alongside locational and environmental factors play a stronger or weaker role on survival rates contingent upon the types of firms considered and the contextual parameters employed by the researchers (Bartelsman, Scarpetta, and Schivardi 2003; Fotopoulos and Louri 2000; Fritsch, Brixy, and Falck 2006; Helmers and Rogers 2008).

Overall, the growing body of scholarly research on firm survival means that there is quite a nuanced understanding of why some firms survive and others wither. However, a potential gap in our knowledge is the extent to which the factors most commonly impacting 
upon survival rates are significant when analysing firms at a more micro-spatial level. In particular, the current research base has largely ignored the factors influencing the survival of firms located within a particular region. This would seem to be an important omission given the growing recognition that differences in localised sub-regional contextual and cultural factors are found to impact upon entrepreneurship (Huggins and Thompson 2014; 2015). Given this, it may well be the case that localised micro-spatial environments have a role to play in determining the survival of a firm. This is of particular relevance to entrepreneurship and business support policy, and the need for such policies to be sufficiently attuned and tailored to local business environments (North and Smallbone 2006; Thompson, Jones-Evans, and Kwong 2012). Such relevance is likely to be highly significant for localities situated in peripheral regional landscapes as manifest by low levels of economic development and sustainable entrepreneurship.

As a result of an apparent knowledge gap, the aim of this paper is to analyse the factors impacting upon firm survival across the micro-spatial local environments of a peripheral region, based on the case of Wales in the UK. The paper seeks to analyse the extent to which the human capital, growth motivation and location theories of firm survival best explain the within region context. It attempts to outline how these theories, although operating at different levels, may be integrated. In particular, it aims to contribute to both scholarly and policy level debates that increasingly acknowledge the heterogeneity of regional environments, and the requirement for differentiated solutions across these environments. In doing this, it attempts to move beyond analyses that have traditionally focused on the study of success factors in leading economic regions, and aims to provide new findings on the determinants of firm survival in the multitude of regions that remain relatively peripheral to the core regional engines of economic growth within national economies. Drawing on data from over 1,000 firms formed in the late 1990s, a multivariate approach is adopted to isolate the impact of variables through the use of binary logistic regression modelling.

The remainder of the paper is structured as follows. Section 2 outlines the nature of entrepreneurship in peripheral regions and how this affects survival before outlining the concepts framework and hypotheses covered by the study. Section 3 introduces the data used within this study and the methods used to analyse the various relationships hypothesised in Section 2. The results are presented in Section 4. Section 5 discusses the implications for the role of entrepreneurship and firm ownership in economic development as well as the 
implications for policy to support entrepreneurial endeavours, with Section 6 concluding the paper.

\section{Theories of Firm Survival}

This section begins by discussing the importance of the role played by entrepreneurs and SMEs in more peripheral regions such as the case study region of Wales studied in this paper. The remaining subsections present and critique the key theories relating to firm survival human capital, growth motivation and locational conditions - as a means of generating a series of hypotheses for empirical analysis.

\section{Entrepreneurship and Survival in the Periphery}

Entrepreneurship is often associated with highly successful regional economies where knowledge spillovers provide opportunities for entrepreneurs, and the SMEs they run, due to their flexible and innovative natures (Audretsch, Hülsbeck, and Lehmann 2012; Lawton Smith et al. 2013). However, other regions which are more peripheral and less successful often look to boost entrepreneurship to try to aid economic development (Stephens and Partridge 2011; Huggins and Williams 2011; Baumgartner, Pütz, and Seidl 2013; Stephens, Partridge, and Faggian 2013). Empirical evidence confirms the links between new firm creation, business ownership (particularly in high growth sectors such as the creative industries) and economic growth and development (Piergiovanni, Carree, and Santarelli 2012; Koster and van Stel 2014), although this is not necessarily the case for more rural areas (Anderson, Wallace, and Townsend 2015).

The longstanding nature of uneven regional spatial development within and across nations has meant that there has long been an interest in core-periphery divides (Krugman 1991; Forslid and Ottaviano 2003). Various definitions have been used to understand and describe what constitutes a peripheral region, and the extent to which this relates to being economically - particularly in relation to the financial system (Gardiner et al. 2013) - or geographically peripheral, although the two often coincide (Combes and Overman, 2004). Dinis (2006) describes peripheral regions as those that are distant and remote territories. For example, in assessing which regions can be classed as peripheral, Keeble, Owens and Thompson (1982) use proximity by road to economic activity within the EU as one measure. Others, however, have argued that the development of information and communications technologies (ICT) have made such proximity less important (Irvine and Anderson 2008). It can also be argued that spatial proximity forms but one dimension of proximity along with 
cognitive, organizational, social, institutional and other forms (Boschma 2005). It should also be noted that although regions that are relatively rural in nature are often those considered to be peripheral, this is not always the case, and the two concepts are distinct (Dinis 2006).

In the context of the empirical analysis presented in the paper, Wales can be viewed as a peripheral and relatively less successful region. Situated on the West of the British Isles, it is also one of the most sparsely populated regions of the UK, with much of the region being rural in nature, with the exception of some larger agglomerations mostly along the south coast. Overall, the performance of the Welsh economy has lagged that of the UK as a whole over the latter part of the twentieth century and into the twenty first century (Chatterji and Dewhurst 1996; Jones and Henley 2008). It is one of the 12 government office regions (GORs) of the UK, and along with Northern Ireland and Scotland has a degree of autonomy over policy through the formation of its own government in 1999, allowing it to develop its own entrepreneurship support policies (Yoo, Mackenzie, and Jones-Evans 2012; Jones and Colwill 2013; Jones-Evans 2015; Rhisiart and Jones-Evans 2016). Nevertheless, according to the Global Entrepreneurship Monitor (GEM) study, entrepreneurship as captured by those starting and running new businesses is lower in Wales than the UK average (Levie and Hart, 2013).

Like other weaker regions, there is also evidence of the persistence of low entrepreneurship rates, so that future entrepreneurial activity along with the survival of existing entrepreneurship are affected through the social norms and legitimisation of entrepreneurship generated alongside limited role models and networking opportunities (Andersson and Koster 2011; Bosma et al. 2012; Fritsch and Wyrwich 2014; Bastesen and Vatne 2014; Kibler, Kautonen, and Fink 2014). Policy interventions have often looked to bring entrepreneurs together, although the degree of success is often dependent on the infrastructure and institutions developed (Fuzi 2015; Murphy, Huggins and Thompson 2015).

Frequently, these regions have a traditional reliance on heavy industry, which has declined with deindustrialisation (Benneworth 2004; Tödtling and Trippl 2005). This has led to higher levels of unemployment and limited growth, which reduces the opportunities for business starts and can lead to those that do start being more marginal (Lee, Florida, and Acs 2004). Local economic conditions are also likely to play an important role in firm survival given the reliance that small firms often have on their local markets for custom (Gorton, 1999; Williams et al. 2009). Also, lower levels of agglomeration with a more rural or inaccessible nature can limit the markets readily available for output. Studies of peripheral regions across the world indicate that a lack of access to major markets is perceived to be a 
problem for survival despite the existence of potential opportunities (North and Smallbone 2000; Tödtling and Trippl 2005; Felzensztein, Gimmon, and Aqueveque 2013; Amorós, Felzensztein, and Gimmon 2013).

The exclusion from important markets can limited the potential to innovate and as such may jeopardise the adaptability and survival of enterprises in more peripheral areas (McAdam, Reid, and Shevlin 2014). This can make efforts to boost networking, internationalisation and the provision of relevant infrastructure key in overcoming the problems imposed by a region's peripheral nature (Arbuthnott and von Friedrichs 2013; Besser and Miller, 2013). On the order hand, it should also be acknowledged that rural areas even in peripheral regions often have a strong tradition of small business ownership (Keeble and Tyler 1995; Warren-Smith and Jackson 2004; North and Smallbone 2006; Brooksbank, Thompson, and Williams 2008). This means that the factors affecting the survival of businesses in peripheral regions such as Wales are likely to vary considerably across the region, with some areas more distant from larger markets whilst others contend with the effects of deindustrialisation.

The weaker enterprise culture and economic conditions present could lead to entrepreneurs rationally relocating from peripheral lagging regions to more dynamic successful core regions (Kaufmann and Malul 2015). This can also occur within regions, as is found to be the case for more educated Welsh speakers moving from West Wales to East Wales, particularly the capital city Cardiff (Drinkwater and O'Leary 1997; Jones-Evans, Thompson, and Kwong 2011). This obviously creates a negative spiral, particularly with the withdrawal of strong role models for future entrepreneurs to follow (Bosma et al. 2012). This migration would also tend to reduce the survival prospects of firms in the peripheral region. A wider issue is that poorer employment prospects in general will tend to lead to an outward migration of more educated and creative individuals as well possibly suppressing human capital acquisition of those that remain (Malul 2015). This reduces the quality of latent entrepreneurs in the population and reduces the talent available for existing enterprises, limiting their likelihood of success (Millán et al. 2014).

As outlined above entrepreneurship, is frequently seen as key to generating economic development in more peripheral regions such as Wales, but conditions in such regions are not necessarily conducive to encouraging entrepreneurship or ensuring its survival. The following sub-sections now move on to outlining the key theories relating to those factors associated with survival that might help to explain differences in entrepreneurial survival within peripheral regions. 


\section{Location, Human Capital and Growth Motivation}

As outlined above entrepreneurial activity in peripheral regions is frequently encouraged as a source of growth (Huggins and Williams 2011; Baumgartner, Pütz, and Seidl 2013; Stephens, Partridge, and Faggian 2013), but the nature of the location as well as the work force skills and motivations behind entrepreneurial engagement can limit the prospects and even survival of these firms (Bosma et al. 2012; Amorós, Felzensztein, and Gimmon 2013). Gimeno et al.'s (1997) threshold model of entrepreneurial exit illustrates that the decision to exit entrepreneurship is in part determined by the performance of the business venture. However, there is no particular level of performance for all entrepreneurs below which businesses are closed. Instead, it is argued that entrepreneurs have individual performance thresholds that must be met, which vary depending on the: alternative employment opportunities available, non-pecuniary benefits of entrepreneurship, such as pleasure of being your own boss and time flexibility; and the practical difficulties of moving to alternative employment, the switching costs (Gimeno et al., 1997). This means that exit can be made more or less likely through a factor affecting performance and/or the threshold of performance. Given that the threshold of performance is hard to capture, studies have generally considered the overall effect of factors on performance and the threshold through survival (Criaco et al. 2014; Di Tienne and Cardon 2012).

In general, locational, human capital and growth motivation factors may impact at different levels on the survival prospects of the firms. The potential influences on firm survival prospects at the three different levels are illustrated by Figure 1.

In terms of locational factors, although firms operating in any region will still be affected by national or internationally originating macroeconomic shocks (Congregado, Golpe, and Parker 2012), the local economic conditions and resources available may also impact on survival (Lee, Florida, and Acs 2004; McAdam, Reid, and Shevlin 2014). Therefore, the location of the firm may increase or decrease the likelihood of survival through the threats faced and opportunities available that originate from outside the firm. Local economic conditions will also have an impact on the performance threshold. Greater aggregate demand from a thriving local economy will boost performance making survival more likely, but at the same time it has the potential to raise the performance threshold as the outside options available also become more attractive.

\section{PLEASE INSERT FIGURE 1 ABOUT HERE}


At the micro level of the firm, the entrepreneur clearly plays a key role in the future of her firm (Brüderl, Preisendörfer, and Ziegler 1992; Acs, Armington, and Zhang 2007). The entrepreneur's influence can be delineated into two levels: the resources that they bring to the firm, in terms of their skills, as well as their desires and motivation for the firm. In the case of human capital, it is often associated with improved entrepreneurial performance (van der Sluis, van Praag, and Vijverberg 2008). Higher levels of human capital is associated with greater ability to identify and exploit opportunities (Ramos-Rodríguez, Medina-Garrido, Lorenzo-Gómez, and Ruiz-Navarro 2010). Understandably other studies find that certain types of human capital are associated with the survival of the firm (Criaco et al. 2014). More general or industry level human capital may actually lower survival prospects by opening up further employment opportunities, which raises the performance threshold that must be achieved to remain entrepreneurially active (Criaco et al. 2014).

Along with the importance of human capital, there is the issue of how such resources are utilised. The motivation behind a business start and the strategies pursued may be more or less commercially focused, with lifestyle factors often of particular importance to some entrepreneurs (Herslund 2012). Here the presence or otherwise of human capital resources may influence the achievement of strategies that increase the survival prospects of the firm (Wiklund and Shepherd, 2003). If the entrepreneur chooses alternative development paths for their venture, this makes the ability to grasp growth opportunities less important. This is reflected in the connection between growth motivation and the performance threshold through its influence on psychic income (Hansen and Hamilton 2011).

It is important to recognise is that locational, human capital and growth motivation influences may be interrelated. For example, the influences from the location may reduce competition and expose entrepreneurs to a culture where the acquisition of wealth and personal success are less important (Huggins and Thompson 2015). Equally, locational factors in peripheral regions may be part of a process that leads to a depletion of human capital resources (Kaufmann and Malul 2015; Malul 2015), so that the average latent entrepreneur will be less well placed to exploit available opportunities (Millán et al. 2014). These factors may also influence the types of entrepreneurial activities and ambitions sought by legitimising or otherwise certain activities through the community culture created (Etzioni 1987; Jack and Anderson 2002; Anderson and Smith 2007). For less skilled entrepreneurs, ambitions associated with growth and longer term success may be perceived to be out of 
reach, reducing entrepreneurial resources by placing bounds on the opportunities available and subsequently altering the behaviours undertaken (Capelleras et al. 2016).

However, the levels, i.e. the three factors, having the greatest importance on the survival prospects of firms in more peripheral areas remains unclear. If policymakers wish to encourage entrepreneurship that is lasting and acts as a key element of regional development, they should consider all three levels. However, the policies that will encourage firm survival at each level will differ considerably in nature. This means that in order to prioritise resources it is of importance to identify which is the most influential level. The following subsections consider the three levels of influence on survival in more detail and establish a number of testable hypotheses in relation to each.

\section{Locational Conditions}

The locational conditions thesis suggests that the spatial environment within which a firm operates will have an effect on survival prospects (Hannan and Freeman 1977; Singh and Lumsden 1990; Vaessen and Keeble 1995; Burger, van Oort, and Raspe 2011; Stephan 2011). Figure 2, which seeks to disaggregate in more detail the factors relating to the three broad theories of firm survival shown by Figure 1, indicates that location will have both direct and indirect effects by influencing the growth strategies that may be followed by firms based on their geographical location and scope (Etzioni 1987; Jack and Anderson 2002; Morrison, Breen, and Ali 2003; Anderson and Smith 2007). For example, some locations may be more sensitive to economic shocks than others, but it is the ability to adapt and recover in the aftermath which often marks out more resilient locations (Martin 2012b). This means that as well as potentially lacking entrepreneurial activities to aid readjustment, weaker locations may also lose existing entrepreneurship where recoveries does not occur in time to prevent the exit of those overly reliant on local demand.

\section{PLEASE INSERT FIGURE 2 ABOUT HERE}

Locational factors generally relate to the local industry within which a firm operates, or alternatively - and potentially important for peripheral regional economies - the local economic conditions in the market as a whole. Research considering the particular characteristics of industries have suggested a number of influences that are often interrelated: the level of competition, clustering, stage of industry cycle, technological intensiveness, barriers to entry, as well as demand conditions and a minimum efficient scale (Cefis and 
Marsili 2005; Fritsch, Brixy, and Falck 2006; Helmers and Rogers 2008; Wennberg and Lindqvist 2010; Raspe and van Oort 2011). In terms of competition, where entry and exit costs are higher and involve a greater sunk component, the probability of failure is reduced (Helmers and Rogers 2008; Fotopoulos and Louri 2000). This switching cost effect operates through the threshold of performance as shown by Figure 2.

In terms of the location of the start-up, local industry density may also play a role. Two opposing relationships are suggested between industry density and survival: a negative competition effect (Stuart and Sorenson 2003); and a positive benefit from localisation effects (Renski 2011). Weterings and Marsili (2015) indicate that no single rule applies, finding that whilst business exits by closure fall when industry density is greater, the probability of exit via a merger or acquisition by another firm increases. They also suggest that whilst survival and 'successful' exits via mergers and acquisition are increased for manufacturing firms, the opposite is true for services, where competition has an overall negative impact on survival, making closure more likely. Renski (2015) finds mixed evidence and suggests that much of the positive effect of localisation economies reflects the greater industry specific work experience of founders. Although evidence is mixed, it does appear that industry density tends to support survival when wider geographical areas are considered (Renski 2011; De Silva and McComb 2012):

Hypothesis 1a: A greater local concentration of firms in the same industry will increase the probability of survival.

As entrepreneurs generally tend to create ventures close to their homes (Mueller and Morgan 1962; Sorensen and Audia 2000), it is likely that successful entrepreneurs will generate greater levels of local economic development (Blackburn and Ram 2006). Furthermore, there is evidence that those areas with higher rates of GVA growth and employment growth have higher firm survival rates (North et al. 2003; Fritsch, Brixy, and Falck 2006):

Hypothesis 1b: Local economic growth will positively influence the probability of firm survival.

Conversely, depressed rates of local employment and income are likely to reduce the performance of firms, as well as reducing alternative employment opportunities (Gimeno et al. 1997; Fotopoulos and Louri 2000; Audretsch and Dohse 2007). Thus, local economic 
conditions influence both the performance of enterprises and the threshold of performance through the outside options available (Figure 2).

Within the context of more peripheral regional economies, one group of entrepreneurs that often attract considerable attention from the media, policymakers and academia are those entering from unemployment (Taylor 1996; Kosanovich et al. 2001; Kelly, Mulvey, and Lewis 2002; Blanchflower 2004; Santarelli and Vivarelli 2007). Although entrepreneurship has been seen as a potential solution for long term persistent unemployment, others have noted that its potential to overcome deprivation as a whole may be limited (Blackburn and Ram 2006; Thompson, Jones-Evans, and Kwong 2012). Lower opportunity costs for the unemployed may make entrepreneurial entry more attractive (Evans and Leighton 1989), but studies also find that exit is more likely (Gray 1990), as the unemployed are likely to have access to fewer resources and will be less aware of the opportunities that are available (Arenius and De Clercq 2005). This means that locational influences will potentially have an indirect effect on survival through the brain drain effect noted above and shown in Figure 2 (Kaufmann and Malul 2015; Malul 2015).

In general, locational context is likely to play an important role not only in the rationale for undertaking entrepreneurial activities (Birley and Westhead 1992; Jones-Evans Thompson, and Hill 2008; Santarelli et al. 2009; Williams and Williams 2014), but also the nature of the activities undertaken (Frankish, Roberts, and Storey 2010), as well as the hurdles that need to be overcome in order to survive (Rouse and Jayawarna 2006; Williams and Williams 2011). It is clear that weaker locations, with higher unemployment and lower wages may induce entrepreneurship due to necessity driven motives that reduce the likelihood of survival (Bergmann and Sternberg 2007; Santarelli and Vivarelli 2007).

Hypothesis 1c: Higher levels of unemployment will reduce firm survival rates.

Although peripheral regions need not be rural in nature, the definitions usually applied relate to a degree of isolation from the largest most vibrant core economic regions (Dinis 2006). This means that the scale of proximate markets may influence survival. The urban-incubator hypothesis suggests that larger urban areas will provide an environment more conducive for start-up activity from increased information circulation with customers and suppliers (Vernon 1960; Renski 2008; Lejpras and Stephan 2011; Pe'er, Vertinsky, and Keil 2016). This is particularly important for innovative and rapidly changing sectors (Malecki 1990; Agarwal 1996, 1998; Agarwal and Audretsch 1999; Renski 2011). Consistent with this, empirical 
evidence finds that agglomeration effects are most important for smaller firms (Fotopoulos and Louri 2000). Haapanen and Tervo (2009) suggest that weaker labour markets in rural areas of Finland actually decrease the likelihood of exit in the first five years of a firm's existence, but beyond this point it appears that enterprises operating in urban areas may benefit from the agglomeration effects. US evidence also indicates that the relationship between urbanisation and survival may vary across industries with both positive and negative results found (Renski 2011). In general, however, it can be hypothesised that agglomeration effects will be positively related with firm survival rates.

Hypothesis 1d: Local agglomeration will increase the probability of firm survival.

\section{Human Capital}

In most firms the entrepreneur as the dominant decision maker has a considerable influence on both the performance and future survival of the firm (Brüderl, Preisendörfer, and Ziegler 1992; Acs, Armington, and Zhang 2007). In particular, their human capital is likely to not only influence the performance of the business, but as indicated in Figure 2 the threshold relevant to continued activity as it influences the opportunity cost faced through the alternative employment opportunities available (Bosma et al. 2004; van der Sluis, van Praag 2008). Based on this approach, studies of entrepreneurial exit have traditionally used an expected utility framework, in which entrepreneurs attempt to maximise the return on their human capital (Becker 1965). This profit stream will be net of opportunity costs, for example those associated with alternative employment opportunities, and may also incorporate intangible benefits such as flexibility and feelings of independence and freedom (Blanchflower and Oswald 1990; Carter et al. 2003). Figure 2 shows how human capital's influence on this psychic income will be indirect operating through the growth motivation as it imposes limitations on the strategies open to the entrepreneur (Morrison, Breen, and Ali 2003; Capelleras et al. 2016). Although some studies particularly those concentrating on high-technology or knowledge intensive sectors have also found generic human capital of this type to be insignificant (Grilli 2011), others have found human capital represented by formal education to positively influence survival (Millán, Congregado, and Román 2012), which leads to the following hypothesis:

Hypothesis 2a: Human capital from formal education will positively influence firm survival. 
In general, human capital theory suggests that there are general and specific forms of human capital, where the former is easier to transfer from one occupation to another, but the latter is likely to yield higher returns in the appropriate context (Becker 1975; Saridakis, Mole, and Storey 2008; Ganotakis 2012). Within the context of longer term firm survival, the general human capital associated with education and work experience is expected to boost both firm performance and survival through greater access to resources allowing for more successful identification and exploitation of opportunities (Bates 1990; Davidsson and Honig 2003; Gimmon and Levie 2010; Ganotakis 2012; Millán, Congregado, and Román 2012).

Experience as captured by age may act as an additional source of human capital, but opportunity costs of time (Becker 1965) and risk aversion are also likely to increase with age (Morin and Suarez 1983). For instance, both factors are likely to increase the incentive to exit and harvest any value, or minimise any losses rather than continue with uncertain returns, thus operating indirectly through growth motivation (Lévesque and Minniti 2006; Grenadier and Wang 2007; Van Witteloostuijn 1998). Given the counteracting forces of age and experience, it is understandable that some studies have found an inverted U-shaped relationship (Cressy 1993; Holtz-Eakin, Joulfaian, and Rosen 1994; Wennberg et al. 2010). Nevertheless, the weight of evidence suggests a positive relationship between general human capital and firm survival:

Hypothesis 2b: Human capital from experience will positively influence firm survival.

Alongside general human capital factors, more specific human capital associated with elements of entrepreneurship gained through experience such as prior business ownership and management experience have been associated with increased survival prospects (Townroe and Mallalieu 1993; Starr and Bygrave 1992; Politis 2005; Gimmon and Levie 2010). Even business failures could provide valuable knowledge and skills to be utilised in future business starts (Audretsch and Thurik 2001), as well as a less negative view of failure (Politis 2008). As a counter to this, scholars including Starr and Bygrave (1992), Rerup (2005) and Simon, Houghton, and Aquino (2000) highlight the potential of prior entrepreneurial experience to bring liabilities including conservative inflexible approaches, a fixation on the past and lower motivation. In particular, empirical evidence suggests that business failure is less likely for more experienced entrepreneurs entering a new spell of business ownership (Taylor 1999; Holms and Schmitz 1996; Quandrini 1999; Unger et al. 2011; Rauch and Rijsdijk 2013): 
Hypothesis 2c: Rates of entrepreneurship specific human capital from prior business ownership will positively influence firm survival.

\section{Growth Motivation}

Overall, the human capital possessed by an entrepreneur may help explain why some entrepreneurs and their firms within a regional economy are more likely to survive and remain within the market. However, this does tend to imply that the entrepreneurs themselves have no control over their fates. One particular course of action that could have profound implications for survival is the capability to grow and accumulate sufficient resources to withstand external shocks (Caliendo, Fossen, and Kritikos 2010; Coad et al. 2013; Coad et al., 2016). However, a counter argument to this thesis is provided by Delmar, McKelvie, and Wennberg (2013) who find a negative relationship between growth in one period and survival in the next in the case of knowledge intensive start-ups, which they suggest may relate to growth itself being a risky activity. A stream of literature has modelled the growth of ventures as following a random walk due to competition from rivals, making it difficult to identify factors leading to better performance, particularly for new ventures with little previous history (Gibrat 1931; Levinthal 1991; Henderson, Raynor, and Ahmed 2012). This would mean that although growth may increase the chances of survival, it is extremely difficult to identify which firms will grow, with only a small proportion of variance captured by models (Coad et al., 2016), and therefore making it just as difficult to identify firms that are more likely to survive.

Despite these difficulties, however, it is recognised that not all entrepreneurs have the same ambitions, and intentions for their businesses, with some seeking to grow their businesses, whilst others may only seek greater independence and autonomy (Mochrie, Galloway, and Donnelly 2006; Block and Wagner 2010; Hansen and Hamilton 2011; Douglas 2013). A heightened growth motivation has been associated with those entrepreneurs who seek opportunities, innovate and are instinctive in their nature (Morrison, Breen, and Ali 2003). It is argued that the actual growth they achieve is strongly linked to these intentions and ultimately to an entrepreneur's' belief that they can achieve the desired outcome (Gray 2000; Maki and Pukkinen 2000; Morrison, Breen, and Ali 2003). Empirical studies have found evidence linking growth aspirations and intentions with achieved growth levels (Barringer, Jones, and Neubaum 2005; Delmar and Wiklund 2008; Moen, Heggeseth, and Lome 2016). This relationship, as suggested above, is likely to be moderated by the 
resources available, including those associated with human capital (Wiklund and Shepherd 2003).

Unlike the data used in this study, many datasets do not include data on the growth motivations of entrepreneurs. Growth, as discussed above, is therefore assumed to be random, and only after time passes and resource accumulation is realised does it become easier to predict survival (Coad et al., 2016). In this study we are able to hypothesise that those entrepreneurs with a greater general growth motivation will be more likely to survive, as they are more likely to have sufficient accumulated resources to withstand negative competitive and macroeconomic shocks.

Hypothesis 3a: Firms established by entrepreneurs that are generally growth motivated are more likely to survive.

Closely linked to sales growth, is a desire to expand markets served geographically (Moen, Heggeseth, and Lome 2016). Those entrepreneurs with an orientation toward geographical market expansion may provide a particular commitment and platform for rapid growth, with firms targeting their products at national rather than local markets found to be more likely to survive (Brüderl, Preisendörfer, and Ziegler 1992; Sapienza et al. 2006; Boso, Story, and Cadogan 2013). Closely related to this, a greater dependence on a narrow range of customers and/or a smaller variety of products may reduce the probability of survival (Reid 1991; Reid and Smith 2000). This appears to imply that where local markets are weaker, it is important that firms attempt to expand geographically to overcome the limitations on growth this imposes (Lee et al. 2012).

Coeurderoy et al. (2012) indicate that with regard to internationalisation, it is not internationalisation per se that increases survival, but rather a strong commitment to either low or high degrees of internationalisation. A peripheral regional context may influence the role played by an entrepreneur's growth motivation in terms of survival if there is less competition between businesses, and small niche businesses are able to operate successfully (Stearns, Carter, and Reynolds 1995). In many regards, this is an unexplored element of many survival studies. Entrepreneurs may fall into two categories: those operating in relatively geographically constrained but less competitive niches; and those operating in markets served by firms based in a larger geographical area, but with a wider variety of growth opportunities available. Overall the diversification of selling to a wider spread of customers would be expected to boost survival: 
Hypothesis 3b: Firms established by entrepreneurs with a relatively geographically wide market orientation are more likely to survive.

\section{Data and Methods}

This study of firm survival makes use of survey data originally collected in 2001 and updated in 2012. The data was originally collected as part of the evidence base for the Welsh Development Agency's (WDA) Entrepreneurship Action Plan (EAP). This data relates to firms initiated between 1995 and 1999, so all firms had progressed beyond the start-up stage and were relatively established at the initial point of contact. This means that the sample will tend to capture the persistence of business ownership and entrepreneurial activities rather than the initial selection mechanism that leads to many new ventures failing to complete the start-up process. The sample of surveyed firms was selected to be representative of the business population in Wales. This sample was derived from two sources: the Financial Analysis Made Easy (FAME) database of UK incorporated firms from Bureau van Dijk; and the Equifax database, which contains additional information on non-incorporated businesses. The data derived from those two sources was then merged and cleaned to remove duplicate listings. As a result, the sample population consisted of 3,251 ventures commencing operation in Wales between 1995 and 1999.

Data collection was based on a telephone survey utilising an external telemarketing company, which resulted in 1,572 responses (a response rate of 48.3 per cent). The survey was originally intended to provide information about those members of the Welsh population who successfully created businesses and the nature of these businesses. As such, data was collected that provides insights into the following: general business information covering turnover, operating status, main export markets; demographic characteristics of entrepreneurs including their gender, age, ethnicity, educational attainment; entrepreneurial history such as previous business ownership and employment histories plus perceptions of management skills; details of business development including support services accessed and required, reasons for establishing businesses, and business constraints.

A small group of 14 businesses indicating their legal status as a social enterprise were excluded from the analysis as they were likely to be atypical of the sample. The sample of responses with complete data after excluding social enterprises and those firms where postcodes could not be matched to the national postcode databases consists of 1,425 
businesses. A vast majority of these firms (1,279 firms; 89.8 per cent) are micro-enterprises with less than 10 employees. Of the remaining firms, 137 (9.6 per cent) are small (10 to 49 employees) and 9 (0.6 per cent) are medium (50 to 249 employees) sized firms. This is a good match for the proportions from the full population of businesses in Wales: 90.3 per cent micro, 7.9 per cent small, and 1.4 per cent medium sized firms.

The analysis presented below investigates the survival of these businesses over the ten years following the initial survey and data collection. As firms in the original sample took a variety of different legal forms a variety of methods had to be employed to establish the continuing existence or otherwise of the businesses. For those registered as limited companies, their continuing existence has been identified through the current FAME database, as this contains listings for all limited companies and organisations with charitable status. To confirm their existence and active trading status, their names and telephone numbers were checked using an Internet search to identify the presence of an up-to-date web presence. Sole traders and partnerships were harder to identify, and the first stage of establishing their continuing existence was through the use of telephone directories. Again a search for a web presence was used as a confirmatory step. This was undertaken for both firms identified through the business directories and those that were not. Where a web presence was found for a sole trader or partnership, but no phone listing was found, the FAME database was searched in case there had been a change in legal form since the initial survey in 2001.

The method of identifying the survival or otherwise of the firms, means that the survival variable relates to the enterprise created rather than the status of the entrepreneur. This means exits will relate more frequently to what Wennberg et al. (2010) describe as liquidation, rather than harvest sales. Where a business is successful, an entrepreneur moving to alternative employment is likely to seek a sale of the enterprise and therefore the business itself will continue to exist. It is possible that some firms will close when relatively successful because of the alternative employment opportunities available to the entrepreneur and no opportunity to sell is available, but this is likely to be very rare. Some businesses may be bought by rivals, and therefore cease to exist as independent entities (Grilli 2011). Ideally, the date of exit would be used here to model the survival prospects of the businesses over the period of study. Unfortunately, data recording the exit dates of sole-traders and partnerships over longer periods, as studied here, are extremely difficult to obtain. As a vast majority of SMEs in the UK are not limited companies, in order to examine the long term persistence of these businesses it is therefore necessary to utilise a dependent variable that only captures 
whether the firm survived or exited during the period of interest, rather than the specific timing of the exit.

As addressed above, the existing literature indicates that survival may be influenced by a large variety of factors. To test the hypotheses set out in section 2 it is necessary to adopt a multivariate approach. This allows the hypotheses to be tested simultaneously whilst controlling for other influences. As the survival variable is discrete rather than continuous in nature ordinary least squares regressions are inappropriate. Instead a binary logistic regression approach is adopted here.

As outlined in the preceding section three main groups of variables linked to survival can be identified: human capital (general and entrepreneurially specific), growth motivation; and locational factors. The operationalisation of the individual variables are outlined in more detail below. Starting with the human capital variables, three separate measures are included. General human capital is captured by formal education and experience (age). In the case of formal education, dummies are included to represent the two extremes of the range, those with no formal qualifications and those with university degree level qualifications or higher. Experience is captured by the age of the entrepreneur and is represented by dummies for those older and younger than the prime business ownership range of 35 to 49 years of age. This comparison is based on the findings of studies such as the Global Entrepreneurship Monitor (GEM), which indicate that the 35 to 44 years age group are most likely to be involved in starting or running a new business (Hart et al. 2015). As noted previously, this is where the need to acquire more experience is balanced by the requirement for sufficient time to achieve a return on investment (Kim 2007). Outside of this range, the expectation is that the survival of the enterprise will be compromised either through a lack of relevant experience or a desire to retire (Andersson Joona 2010; Haapanen and Tervo 2009).

It is acknowledged that the survival of the enterprise is not solely reliant on the human capital of the entrepreneur, but that they will be able to draw upon the human capital of their employees, especially as these enterprises have moved through the start-up phase. However, scholars such as Blackburn, Hart and Wainwright (2013) and Hansen and Hamilton (2011) note how the owner-managers of SMEs play an important role in determining the strategies pursued, are a key resource for small firms, and ultimately have an important influence on the performance achieved by the firm. These direct and indirect influences on survival are shown by Figure 2, with influences on both the performance of the firm and the performance threshold. The specific human capital variables are those associated with entrepreneurial experience that are likely to be of value in the business. Recent experience is ascertained 
through responses to the question: 'What where you doing before you established your current businesses?' with the following response categories available: out of work, full time education, self-employment, or employed by others. The first four are included as dummies in the regression and compared to the base category of being employed by others.

With regard to the growth motivation of firms, we test for the positive effects of growth motivation in general and more specifically a wider geographical market orientation as hypothesised above. To capture the general growth motivation of the entrepreneur, respondents were asked 'how do you see your business developing over the $3-5$ next years?'. Those indicating they expected fast or steady growth, in contrast to staying the same size or declining, we defined as growth orientated in the general sense. In relation to the geographical market orientation of firms and survival, much of the literature has considered the decision to internationalise. Many of these studies have considered high-technology sectors or more innovation focused businesses, but for a majority of businesses in peripheral regions such a focus is not necessarily appropriate (Skuras, Tsegenidi, and Tsekouras 2008). The survey therefore asked respondents 'Where is the main market in which your business operates?'. Respondents were asked to choose between the following, mainly local (within 25 mile radius), Wales-wide, UK-wide, and outside the UK. For the purposes of analysis the last of these two groups were combined, as exporting activities were rare in the sample.

Following the existing literature outlined in section 2, the locational conditions within which the firm operates fall into two main groups: those relating to the local economic environment; and those relating to the industrial competition faced. The market scale element of the local economic environment is represented by the settlement type of the firm's location. The Office for National Statistics (ONS) definition of areas at the mid super output area is employed with areas categorised as: urban, town and fringe, or village and isolated hamlet (ONS 2004). The economic strength of the local authority area is captured by growth in GVA per capita for the period 1997-2002, as well as changes in the labour market between 2002 and 2012, as captured by the unemployment benefit claimant count. The final locational factor is associated with the negative competition (Helmers and Rogers 2008; Fotopoulos and Louri 2000), and positive industry clustering (Wennberg and Lindqvist 2010) effects from industrial density. The variable included in the regression takes the form of a location quotient with the proportion of employment provided by the industry (measured at the 2-digit SIC level) in the local authority area reported as a ratio of the proportion of employment it provides throughout Wales. Data used to create these location quotients were drawn from the UK Annual Business Inquiry (ABI). 
To control for other firm level influences that may affect the survival of the firms, dummies representing broad industry sectors are also included (manufacturing, construction, others) and compared to a base category of the retail and wholesale sector. A dummy for high technology manufacturing (HTM) or knowledge based services (KBS) industries as defined by Eurostat (2009) is also included. These industry controls are included to capture factors such as barriers to entry and sunk investments, which may make survival more likely (Helmers and Rogers 2008). Linked to this, dummies are included for firms taking more formalised legal structures, i.e. partnerships and limited liability companies, in contrast to sole traders. Where more formalised or others are included in the ownership structure switching costs are raised, making exit less likely. The size of the firm is captured by its employment level with firms categorised as micro or small and medium. This is to control for the resources that greater scale provides that have been linked to higher survival through an ability to withstand shocks (Geroski, Mata, and Portugal 2010; Coad et al. 2013). Studies such as Boden and Nucci (2000) suggest that businesses started by female entrepreneurs have lower survival rates. This may reflect a variety of factors that affect the nature of businesses started such as: risk aversion, labour market experience, direct discrimination, and access to finance (Caliendo, Fossen, and Kritikos 2009; Manning and Swaffield 2008; Gicheva and Link 2013; Mueller and Conway Dato-on 2013). Therefore, a gender dummy is included to control for possible differences in survival rates (although some recent studies find limited roles for gender (Coad et al. 2013)).

The main regressions are run using the whole sample of 1,425 firms. As the medium sized firms that make up only 0.7 per cent of the sample are potential outliers we repeated the analysis with these firms excluded, but found no substantial differences in the results produced. However, given the importance of firm size in prior studies we also repeat the analysis on subsamples of micro-firms and the remaining small and medium sized firms.

\section{Results}

Of the 1,425 firms examined within the analysis, 783 (54.9 percent) survived the entire period from 2001 to 2011. This may initially appear high compared to the five year survival rate of firms of 44.4 percent reported for Wales for the period 2005 to 2010 (ONS 2011). However, these figures are not directly comparable, as the Office for National Statistics data refer to the survival rate of newly formed firms, whilst the survey data here included firms that are relatively more established at the point of the survey, so potentially the least viable and less committed entrepreneurs had already exited by this stage (Jovanovic 1982). 
Table 1 shows the proportions of firms surviving when the sample is categorised by the main variables of interest associated with growth motivation, human capital and locational factors. With regard to growth motivation, the chi-square statistics indicate that businesses run by entrepreneurs with general growth motivations are statistically more likely to survive (58.3 per cent survival) than those with no general growth motivation (47.8 per cent). Although a smaller proportion of those businesses with a more restricted local geographical market orientation survived (54.1 per cent) than those selling to regional (56.8 per cent) or national markets (56.1 per cent), the chi-square statistic indicates that survival does not vary by geographical market orientation at a statistically significant level.

Of the human capital measures it is interesting that those measures associated with experience and prior work status are those with significant variation between the groups of firms. The prime age group (35 to 49 years) has the highest survival rate (59.0 per cent). In the case of prior work status, those who were previously self-employed have survival rates similar to the sample average (59.0 per cent). Interestingly, it is those entering from education and training whose businesses are most likely to be still operating, with nearly two thirds of firms still active. Those entering business ownership from unemployment are the least likely to have survived (36.8 per cent).

The highest proportion of firms surviving are found outside agglomerations, with 57.7 per cent surviving in villages and isolated hamlets compared to 53.0 per cent in areas defined as urban. In terms of economic conditions, it is no surprise that a higher proportion of firms survive in localities with higher growth and lower unemployment rises. Where industry density is greater, the proportion of firms surviving is higher. On their own and broken down into groups by above or below the median, of the locational factors only the change in unemployment has a weakly significant effect. Areas that have seen smaller rises in unemployment display higher survival rates. However, given the interconnections found in the literature, and illustrated in Figure 2, it is important to determine whether such factors have an impact when the other human capital and growth motivation variables are taken into consideration, given the uneven distribution of resources across regions such as Wales.

\section{PLEASE INSERT TABLE 1 ABOUT HERE}

In preparation for the multivariate regression analysis Table 2 reports the bivariate correlations between the variables. The Spearman rank non-parametric correlation 
coefficients are reported as a large proportion of the variables are ordinal rather than continuous.

\section{PLEASE INSERT TABLE 2 ABOUT HERE}

Survival is found to be positively correlated with the entrepreneur's general growth motivation at the 1 per cent level. A weaker negative correlation is found for increases in unemployment over the period. The size of the firm clearly plays an important role with a positive significant correlation found with survival. Similarly, survival is correlated positively with firms possessing more formalised legal status, such as partnerships or limited liability companies, in contrast to sole traders. There is also found to be a weakly significant correlation suggesting that businesses started by male entrepreneurs are more likely to survive. Although there are other significant correlations between the independent variables, none of these appear likely to cause problems with multicollinearity as the estimated correlation coefficients are small. The variance inflation factors (VIF) from the regressions confirm this, with the highest value being 2.63 attached to the dummy representing those firms based in the most rural locations (villages and isolated hamlets). This is well below all conventional cut-off points where multicollinearity becomes an issue.

Before introducing the full regression results it is worth assessing whether the groups of variables associated with growth motivation, human capital and locational factors are found to collectively have a significant influence on the probability of survival. Table 3 reports the Likelihood-ratio (LR) test results associated with each group of variables. For the full sample, all groups of variables are found to have a significant effect on survival at the 5 per cent level or better. Growth motivation, human capital associated with business ownership and other prior work status along with location factors are significant at the 1 per cent level. Stratifying the sample by firm size does change the results slightly, with micro firm survival only weakly influenced by general human capital. For the smaller sub-sample of small and medium sized firms, only general human capital and locational factors remain significant at the 5 per cent level.

\section{PLEASE INSERT TABLE 3 ABOUT HERE}

The regressions themselves explain a relatively small amount of the deviation according to the pseudo $\mathrm{R}^{2}$ values, with only 4.9 per cent explained by the full sample regression (Table 4). However, all three estimations are able to reject the null of constant 
probability according to the LR-test. The Hosmer-Lemshow test cannot reject the null of a good fit.

\section{PLEASE INSERT TABLE 4 ABOUT HERE}

Confirming the descriptive statistics presented above, the logit regression indicates that growth motivation is significantly related to firm survival. Those firms started by entrepreneurs with a general growth motivation are 1.5 times as likely to survive as those who intend to maintain or contract the size of their business (hypothesis 3a). No significant effect is found for geographical market orientation (hypothesis $3 b$ ).

In terms of general human capital a positive relationship is found, as suggested by hypothesis $2 b$, as younger entrepreneurs with less experience (aged less than 35 years) are a third less likely to have businesses that survive than those in the prime age group. However, there is also weak evidence that the relationship may have an inverted U-shape, with the firms of older entrepreneurs less likely to survive at the 10 per cent level. Formal educational qualifications have no significant effect on firm survival, rejecting hypothesis $2 a$. Although there are significant differences in the probability of survival of businesses depending on the prior work status of their owners, there is no evidence to support hypothesis $2 c$ as those entering from self-employment are no more likely to have businesses that survive than those entering from employment for others. However, those coming from education or training are more likely to have businesses that survive, whilst businesses started by previously unemployed entrepreneurs are only half as likely to survive.

Of the locational factors, the state of local economic conditions is the most important. Local growth rates prior to the survey significantly increase the likelihood of survival (hypothesis $1 \mathrm{~b}$ ) and there is also evidence that unemployment after the survey reduces the likelihood of survival (hypothesis 1c). However, there is no evidence that agglomeration (hypothesis 1d) or industry density (hypothesis 1a) have any impact on survival.

Of the control variables included, firm size is significant at the 5 per cent level. Small and medium sized firms are twice as likely to survive as their micro counterparts. The legal status of the enterprise does play an important role, but rather than limited liability companies being more likely to survive than sole traders, it is those formed as partnerships where survival is more likely. There is also weak evidence that knowledge intensive businesses operating in more uncertain fast moving industries are less likely to survive, whilst businesses started by men are more likely to survive. Finally, categorising the sample by firm size does 
generally produce similar results, but there are some subtle differences. For those running micro businesses there is weak support for hypothesis $2 c$, with prior experience in selfemployment having a positive effect. The opposite is true for those running small businesses, where a general growth motivation is also no longer found to be important for survival (hypothesis 3a).

\section{Discussion}

The model outlined in Figure 2 illustrates how locational, human capital and growth motivation factors potentially have both direct and indirect influences on firm survival. In particular, location factors determine the opportunities and threats present (Lee, Florida, and Acs 2004; McAdam, Reid, and Shevlin 2014), but also create an environment that determines the human capital available to the entrepreneurial sector (Kaufmann and Malul 2015; Malul 2015), as well as through legitimisation of the types of activities and ambitions that this human capital is driven towards (Etzioni 1987; Jack and Anderson 2002; Anderson and Smith 2007). However, it is the human capital available that allows those opportunities available to be exploited (Ramos-Rodríguez, Medina-Garrido, Lorenzo-Gómez, and RuizNavarro 2010), whilst influencing the types of opportunity sought by affecting growth motivations (Morrison, Breen, and Ali 2003; Capelleras et al. 2016).

Overall, the analysis finds evidence to support the importance of growth orientation, human capital and locational factors on the survival of businesses in a peripheral region such as Wales. However, there is variable support for the particular elements and links within the proposed model. For example, it appears that educational attainment has no significant effect (hypothesis 2a). The desire of this study to understand the longer-run survival of SMEs means that implications for current educational provision need to be considered carefully. It does seem that previous university education does not necessarily provide entrepreneurs with the skills to create enduring businesses, although this may in part reflect more qualified entrepreneurs having a greater variety of employment alternatives (van der Sluis, van Praag, and Vijverberg 2008). However, support is found for general work experience leading to greater survival (hypothesis $2 b$ ), but with some evidence found for an inverted U-shape relationship. On the other hand, previous entrepreneurial experience has limited influence (hypothesis 2c).

For localities in peripheral regions that frequently have lower levels of human capital and are in danger of losing their most talented individuals to other more successful regions (Findlay et al. 2009; Iammarino and Marinelli 2011), or areas within the same region 
(Drinkwater and O'Leary, 1997), this does not provide encouragement that entrepreneurial endeavours will be the best means of retaining such talent given the limited persistence of such enterprises. Studies indicate that aspects of broader well-being such as perceptions of safety and security are not promoted by migration (Iammarino and Marinelli 2011), so those leaving localities in peripheral regions can be encouraged to return due to social ties (Rérat, 2014).

Unfortunately, enterprises started by those moving to localities in more peripheral regions, particularly those with a more rural nature, are less likely to be growth orientated (Anderson, Wallace, and Townsend 2015), which this study indicates to be key for survival (hypothesis $3 a$ ). There have recently been calls for changes to the teaching within university business schools to ensure they equips their graduates with the entrepreneurial skills needed for the modern workplace, and generally for business schools to engage more directly with society and business (Rae 2010; Martin 2012a). As those entrepreneurs straight out of education are more likely to create lasting ventures, this may be a group to target with support before other life and employment experiences reduce their motivation (Kwong and Thompson 2016).

The evidence presented here suggests that although there is evidence of complementarities between traditional and entrepreneurial education missions (Philpott et al. 2011; van Looy et al. 2011), educational reform of some kind is needed or alternatively an acknowledgment that a different type and source of education is required to achieve entrepreneurial objectives. One possible solution is to target support and education at those already operating enterprises to provide the human capital that is appropriate for widening opportunities and promoting a growth motivation (Clifton et al., 2015).

The results relating to locational conditions can be interpreted as being both encouraging and discouraging at the same time. The lack of evidence to support the role of agglomeration (hypothesis 1d) and industry density (hypothesis 1a) in supporting survival is positive in the sense that no locality within a peripheral region is necessarily at a disadvantage because of the lack of such factors. This means that fears about rural and less developed areas in peripheral regions struggling to maintain an enterprise culture (North and Smallbone 2000; Tödtling and Trippl 2005) are perhaps not as big a problem as some studies suggest. However, negatively it is clear that output growth (hypothesis 1b) and lower unemployment (hypothesis 1c) do increase survival. This means that localities already struggling economically are those that are least likely to retain their existing businesses and 
are understandably caught in a negative spiral. This means even within peripheral regions there are difficulties faced with continuing uneven development (Kaufmann and Malul 2015).

Although studies such as that of Cooke et al. (2016) outline the role of local government and educational establishments in encouraging entrepreneurship, the results from the present study indicate that local economic conditions may hinder the survival of these ventures. In particular, it may influence the type of human capital drawn into entrepreneurship, with the results indicating that for those coming from positions of unemployment success is less likely. Equally, although entrepreneurship may provide a quick solution to youth unemployment issues in localities within peripheral regions, it does not appear to produce enduring firms (Rotar 2014). Williams (2004) also warns against lasting negative effects from spells in entrepreneurship at a young age with regard to future career prospects. However, existing studies indicate that it is important for peripheral regions to engage in cross border cooperation whether this is between areas within the regions themselves or across international borders (Cooke et al. 2016; Burdack, Kriszan and Nadler, 2016).

In relation to the findings on growth motivation, there have long been calls for policy to avoid trying to generate more firm starts per se, but rather to focus support on potential high-growth business starts (Shane 2009), and the results presented here suggest that overall growth ambitions are indeed important for survival, especially among micro-firms. Although 'picking winners' is undoubtedly beyond the capabilities of support agencies (Hindle, Yencken, and O’Connor 2011; Mason and Brown 2013), it may be possible to avoid backing some losers. It would appear that the increased scrutiny of the nature of business plans and their identified growth opportunities are areas where attention should be focused. In addition, policies that look to aid the unemployed with starting a business need to be carefully considered. Although there may be benefits for the individual, such businesses would appear to be less likely to benefit a lagging region or its constituent local areas, and may not be the best use of scarce resources. This means that when implementing such policies the links between location, human capital and growth motivation need careful consideration.

In terms of regional enterprise policy more generally, in order to utilise intervention in an efficient and effective manner an understanding of issues with regard to entrepreneurial heterogeneity within a peripheral regional context is clearly important (North and Smallbone 2006). Where policy can perhaps have most influence is in shaping the strategic choices of local small and medium sized enterprises (SMEs) through targeted support (Smallbone, Leigh, and North 1995; Honjo and Harada 2006). However, the results do not suggest a need 
for support policies to formulated at a level that focuses on small scale locally-focused enterprise in deprived areas or for marginalised groups as a means of building capacity and overcoming the disadvantages faced within these communities (Amin, Cameron, and Hudson 2002; Morgan and Price 2011), as the relative opportunity cost of such initiatives is likely to be extremely high (North et al. 2003).

\section{Concluding Remarks}

This study has sought to provide an analysis and understanding of the factors underlying the longer-term survival of firms in a relatively peripheral regional economy. In particular, the impact of human capital, growth motivation and locational conditions were explored. Using the existing literature it was illustrated that these three factors, whilst operating at different levels, are interconnected and as such policies for promoting the survival of entrepreneurial ventures in localities within regions should take a more holistic approach. All three groups of variables were found to play a role, and the study's findings have important implications for future research in a number of respects, especially within the context of more peripheral regional contexts. When considering the influences of growth motivation on survival, it is clear that the strategic choices matter, but more research is required to understand what underpins differences in the decision-making of entrepreneurs within similar locations. Perhaps the most important result from the study is the finding that survival varies significantly within peripheral regions. However, futures studies may wish to explore the extent to which there are interactions between locational influences and the growth motivation and human capital factors. Only by separating out and understanding the influence of the individual linkages outlined in Figure 2 will it be possible to determine, for example, whether reduced growth motivations are an outcome of cultural influences, or the allocation of human capital within entrepreneurial and non-entrepreneurial activities. More generally, it is clear that much more work is required at a localised intra-regional level to fully understand the factors driving longer-term survival within peripheral less successful regions.

Furthermore, relatively little is known, at least qualitatively, about how different patterns of ownership and motivational differences lead to differing survival outcomes. This represents a fundamental issue for future research in the broader area of entrepreneurship and regional development. Although research has now produced a significant pool of evidence relating to the factors that help to initially create the foundations of entrepreneurially conducive local and regional environments, the factors that sustain such environments in the longer-run remain relatively unexplored. This undoubtedly partly due to a lack of relevant 
data sources on survival compared with that available on start-up processes. This study has attempted to build on existing evidence, with the results based on data from a single region in the UK. Although the example of Wales provides a good example of a region with both a legacy of heavy industry and more remote rural areas, the nature of other peripheral regions will tend to vary. It is important, therefore, that future studies seek to draw on a wider pool of regions to assess the extent that the results found here are generalizable to other peripheral regions.

Further work using longitudinal data would provide valuable insights to the evolution of both business and entrepreneurial career development for those following the different entrepreneurial and strategic routes identified in this paper. As studies have highlighted the value of inter-area cooperation on policy (Cooke et al. 2016; Burdack, Kriszan and Nadler, 2016), future work is also required that examines in more depth the dynamics between neighbouring areas and their effect on entrepreneurial persistence. The model developed here has concentrated only on survival as an outcome, but it did incorporate non-pecuniary influences on the exit decision. In terms of investigating broader welfare maximisation and different entrepreneurial motivations (Anderson, Wallace, and Townsend 2015), there is room for further developing the model introduced here to make broader well-being the focus rather than firm survival.

Finally, the study has limitations both in terms of the way that the data was collected, and also the implications this has for the measure of survival. It is, unfortunately, not possible to determine the exact date that firms ceased to exist, and therefore no hazard function can be estimated. In addition, the reasons for non-survival are also unknown. Due to the way that the measure is devised, most non-survival will reflect entrepreneurial failure of some kind; although this is not guaranteed to be the case for all firms. Of further interest is the fate of not only the firms but also their entrepreneurs. It is possible that whilst firms have failed, entrepreneurs may have gone on to use this experience to improve the survival prospects of their subsequent businesses (Audretsch and Thurik 2001).

\section{References}

Acs, Z. J., C. Armington, and T. Zhang. 2007. "The determinants of new-firm survival across regional economies: The role of human capital stock and knowledge spillover." Papers in Regional Science 86 (3): 368-392. doi: 10.1111/j.1435-5957.2007.00129.x

AECOM. 2010. Cardiff 2020. Cardiff: Cardiff Council.

Agarwal, R. 1996. "Technological activity and survival of firms.” Economics Letters 52 (1): 101-108. doi: 10.1016/0165-1765(96)00837-3 
Agarwal, R. 1998. "Small firms survival and technological activity." Small Business Economics 11 (3): 215-224. doi: 10.1023/A:1007955428797

Agarwal, R., and D. B. Audretsch. 1999. "The two views of small firms in industry dynamics: a reconciliation.” Economics Letters 62 (2): 245-251. doi: 10.1016/S01651765(98)00234-1

Amin, A., A. Cameron, and R. Hudson. 2002. Placing the Social Economy. London: Routledge.

Amorós, J. E., C. Felzensztein, and E. Gimmon. 2013. "Entrepreneurial opportunities in peripheral versus core regions in Chile.” Small Business Economics 40 (1): 119-139. doi: 10.1007/s11187-011-9349-0

Anderson, A. R., and R. Smith. 2007. "The moral space in entrepreneurship: an exploration of ethical imperatives and the moral legitimacy of being enterprising." Entrepreneurship and Regional Development 19 (6): 479-497. doi: 10.1080/08985620701672377

Anderson, A. R., C. Wallace, and L. Townsend. 2015. "Great expectations or small country living? Enabling small rural creative businesses with ICT.” Sociologia Ruralis, forthcoming. doi: 10.1111/soru.12104

Andersson, M., and S. Koster. 2011. "Sources of persistence in regional start-up rates evidence from Sweden.” Journal of Economic Geography 11 (1): 179-201. doi: 10.1093/jeg/lbp069

Andersson Joona, P. 2010. "Exits from self-employment: is there a native-immigrant difference in Sweden?” International Migration Review 44 (3): 539-559. doi: 10.1111/j.1747-7379.2010.00817.x

Arbuthnott, A., and Y. von Friedrichs. 2013. "Entrepreneurial renewal in a peripheral region: the case of a winter automotive-testing cluster in Sweden" Entrepreneurship and Regional Development 25 (5/6): 371-403. doi: 10.1080/08985626.2012.748095

Arenius, P., and D. De Clercq. 2005. "A network-based approach on opportunity recognition.” Small Business Economics 24 (3): 249-265. doi: 10.1007/s11187-0051988-6

Audretsch, D. B., and D. Dohse. 2007. "Location: a neglected determinant of firm growth.” Review of World Economics 143 (1): 79-107. doi: 10.1007/s10290-007-0099-7

Audretsch, D. B., M. Hülsbeck, E. E. Lehmann. 2012. "Regional competitiveness, university spillovers and entrepreneurial activity.” Small Business Economics 39 (3): 587-601. doi: 10.1007/s11187-011-9332-9

Audretsch, D. B., and A. R. Thurik. 2001. "What is new about the new economy: sources of growth in the managed and entrepreneurial economies." Industrial and Corporate Change 10 (1): 17-34. doi: 10.1093/icc/10.1.267

Barringer, B., F. Jones, D. Neubaum. 2005. "A quantitative content analysis of the characteristics of rapid-growth firms and their founders." Journal of Business Venturing 20 (5): 663-687.

Bartelsman, E., S. Scarpetta, and F. Schivardi. 2003. "Comparative analysis of firm demographics and survival: micro-level evidence for the OECD countries." OECD Economics Department Working Papers \#348.

Bastesen, J. and E. Vatne. 2014. "Rapid-growth firms: exploring the role and location of entrepreneurial ventures.” In Agglomeration, Clusters and Entrepreneurship: Studies in Regional Economic Development, edited by C. Karlsson, B. Johansson, and R. R. Stough, 159-198. Cheltenham: Edward Elgar.

Bates, T. 1990. "Entrepreneurial human capital inputs and small business longevity.” Review of Economics and Statistics 72 (4): 551-559. 
Baumgartner, D., M. Pütz, and I. Seidl. 2013. "What kind of entrepreneurship drives regional development in European non-core regions? A literature review on empirical entrepreneurship research.” European Planning Studies 21 (8): 1095-1127. doi: 10.1080/09654313.2012.722937

Becker, G. 1965. “A theory of the allocation of time.” Economic Journal 75 (299): 493-517.

Becker, G. 1975. Human Capital, Second Edition. Chicago, IL: University of Chicago Press.

Benneworth, P. 2004. "In what sense 'regional development?': entrepreneurship, underdevelopment and strong tradition in the periphery." Entrepreneurship and Regional Development 16 (6): 439-458. doi: 10.1080/0898562042000249786

Bergmann, H., and R. Sternberg. 2007. "The changing face of entrepreneurship in Germany." Small Business Economics 28 (2/3): 205-221. doi: 10.1007/s11187-006-9016-z

Besser, T. L., and N. J. Miller. 2013. "Community matters: successful entrepreneurship in remote rural US locations.” International Journal of Entrepreneurship and Innovation 14 (1): 15-27. doi: 10.5367/ijei.2013.0104

Birley, S., and P. Westhead. 1992. "A comparison of new firms in assisted and non-assisted areas in Great Britain.” Entrepreneurship and Regional Development 4 (4): 299-338. doi: 10.1080/08985629200000018

Blackburn, R. A., M. Hart, and T. Wainwright. 2013. "Small business performance: business, strategy and owner-manager characteristics." Journal of Small Business and Enterprise Development 20 (1): 8-27. doi: 10.1108/14626001311298394

Blackburn, R., and M. Ram. 2006. "Fix or fixation? The contributions and limitations of entrepreneurship and small firms to combating social exclusion.” Entrepreneurship and Regional Development 18 (1): 73-89. doi: 10.1080/08985620500419566

Blanchflower, D. G. 2004. "Self-employment: more may not be better." National Bureau of Economic Research Working Paper \#10286.

Blanchflower, D. G., and A. J. Oswald. 1990. "Self-employment and the enterprise culture." British Social Attitudes 7: 127-143.

Block, J. H., and M. Wagner. 2010. "Necessity and opportunity entrepreneurs in Germany: characteristics and earnings differentials." Schmalenbach Business Review 62 (2): 154-174.

Boden, R. J., and A. R. Nucci. 2000. “On the survival prospects of men's and women's new business ventures.” Journal of Business Venturing 15 (4): 347-362. doi: 10.1016/S0883-9026(98)00004-4

Boschma, R. 2005. "Proximity and innovation: a critical assessment.” Regional Studies 39 (1): 61-74. doi: 10.1080/0034340052000320887

Bosma, N., J. Hessels, V. Schutjens, M. van Praag, I. Verheul. 2012. "Entrepreneurship and role models.” Journal of Economic Psychology 33 (2): 410-424. doi: 10.1016/j.joep.2011.03.004

Bosma, N., M. van Praag, R. Thurik, and G. de Wit. 2004. “The value of human and social capital investments for the business performance of startups." Small Business Economics 23 (3): 227-236. doi: 10.1023/B:SBEJ.0000032032.21192.72

Boso, N., V. M. Story, and J. W. Cadogan. 2013. "Entrepreneurial orientation, market orientation, network ties, and performance: study of entrepreneurial firms in a developing economy.” Journal of Business Venturing 28 (6): 708-727. doi: 10.1016/j.jbusvent.2013.04.001

Bourdieu, P. 1986. "The forms of capital." in Handbook of Theory of Research for the Sociology of Education, edited by J. E. Richardson, 241-258. Westport, CT: Greenwood Press.

Brockhaus, Sr., R. H. 1980. "Risk taking propensity of entrepreneurs." Academy of Management Journal 23 (3): 509-520. doi: 10.2307/255515 
Brooksbank, D. J., P. Thompson, and R. Williams. 2008. "Entrepreneurial attitudes, intentions and activities - a comparison of urban and rural areas in Wales." International Journal of Entrepreneurship and Small Business 6 (3): 421-436. doi: 0.1504/IJESB.2008.019136

Burdack, J., M. Kriszan, and R. Nadler. 2016. "Towards a sustainable regional economy? The Oberlausitz region in transformation.” in Globalization and Europe's Rural Regions, edited by J. McDonagh, B. Nienaber and M. Woods, 143-164. Abingdon: Routledge.

Brüderl, J., P. Preisendörfer, and R. Ziegler. 1992. "Survival chances of newly founded business organisations.” American Sociological Review 57 (2): 227-242.

Burger, M. J., F. G. van Oort, and O. Raspe. 2011. "Agglomeration and new establishment survival: a mixed hierarchical and cross-classified model.” In Drivers of Innovation, Entrepreneurship and Regional Dynamics, edited by K. Kourtit, P. Nijkamp, and R. R. Stough, 45-63. Berlin Heidelberg: Springer.

Caliendo, M., F. M. Fossen, and A. S. Kritikos. 2009. "Risk attitudes of nascent entrepreneurs - new evidence from an experimentally validated survey." Small Business Economics 32 (2): 153-167. doi: 10.1007/s11187-007-9078-6

Caliendo, M., F. Fossen, and A. Kritikos. 2010. "The impact of risk attitudes on entrepreneurial survival.” Journal of Economic Behavior and Organization 76 (1): 45-63. doi: 10.1016/j.jebo.2010.02.012

Capelleras, J.-L., I. Contín-Pilart, M. Larraza-Kintana, and V. Martin-Sanchez. 2016. "Unemployment and growth aspirations: the moderating role of education." Strategic Change 25 (2): 171-185.

Carter, N. M., W. B. Gartner, K. G. Shaver, and E. J. Gatewood. 2003. "The career reasons of nascent entrepreneurs." Journal of Business Venturing 18 (1): 13-39. doi: 10.1016/S0883-9026(02)00078-2

Cefis, E., and O. Marsili. 2005. "A matter of life and death: innovation and firm survival." Industrial and Corporate Change 14 (6): 1167-1192. doi: 10.1093/icc/dth081

Chatterji, M., and J. H. LL. Dewhurst. 1996. "Convergence clubs and relative economic performance in Great Britain: 1977-1991.” Regional Studies 31 (1): 31-40. doi: 10.1080/00343409612331349458

Clifton, N., R. Huggins, B. Morgan, and P. Thompson. 2015. “An appropriate tool for entrepreneurial learning in SMEs? The case of the 20Twenty Leadership Programme.” Local Economy 30 (5): 534-556. doi: 10.1177/0269094215589310

Coad, A., J. Frankish, R. G. Roberts, and D. J. Storey. 2013. "Growth paths and survival chances: an application of gambler's ruin theory.” Journal of Business Venture 28 (5): 615-632. doi: 10.1016/j.jbusvent.2012.06.002

Coad, A., J. S. Frankish, R. G. Roberts, and D. J. Storey. 2016. "Predicting new venture survival and growth: does the fog lift?” Small Business Economics 47 (1): 217-241. doi: 10.1007/s11187-016-9713-1

Coeurderoy, R., M. Cowling, G. Licht, and G. Murray. 2012. "Young firm internationalization and survival: empirical tests on a panel of 'adolescent' new technology-based firms in Germany and the UK." International Small Business Journal 30 (5): 472-492. doi: 10.1177/0266242610388542

Combes, P.-P., and H. G. Overman. 2004. "The spatial distribution of economic activities in the European Union.” In Handbook of Regional and Urban Economics, Volume 4, edited by J. V. Henderson and J. F. Thisse, 2845-2909. Amsterdam: Elsevier. 
Congregado, E., A. A. Golpe, and S. C. Parker. 2012. "The dynamics of entrepreneurship: hysteresis, business cycles and government policy." Empirical Economics 43 (3): 1239-1261. doi: 10.1007/s00181-011-0516-6

Cooke, G. B., J. K. Burns, S. L. Mann, K. W. J. Vardy, and B. L. Cass. 2016. "The case of Ireland's County Donegal: stimulating rural labour markets via training, tourism and nurturing social enterprise and entrepreneurship.” E-Journal of International and Comparative Labour Studies 5 (1).

Cressy, R. 1993. "Loan commitments and business starts: an empirical investigation on UK data." CSME Working Paper \#12.

Criaco, G., T. Minola, P. Migliorini, and C. Serarols-Tarrés. 2014. ““To have and have not”: founders' human capital and university start-up survival.” Journal of Technology Transfer 39 (4): 567-593. doi: 10.1007/s10961-013-9312-0

Davidsson, P., and B. Honig. 2003. "The role of social and human capital among nascent entrepreneurs.” Journal of Business Venturing 18 (3): 301-331. doi: 10.1016/S08839026(02)00097-6

Delmar, F. 2008. "The effect of small business managers' growth motivation on firm growth: a longitudinal study.” Entrepreneurship Theory and Practice 32 (3): 437-457. doi: 10.1111/j.1540-6520.2008.00235.x.

Delmar, F., A. McKelvie, and K. Wennberg. 2013. "Untangling the relationships among growth, profitability and survival in new firms.” Technovation 33 (8/9): 276-291. doi: 10.1016/j.technovation.2013.02.003

De Silva, D. G., and R. P. McComb. 2012. "Geographical concentration and high tech firm survival.” Regional Science and Urban Economics 42 (4): 691-701. doi: 10.1016/j.regsciurbeco.2012.03.001

De Tienne, D. R., and M. S. Cardon. 2012. "Impact of founder experience on exit intentions." Small Business Economics 38 (4): 351-374. doi: 10.1007/s11187-010-9284-5

Dinis, A. 2006. "Marketing and innovation: useful tools for competitiveness in rural and peripheral areas." European Planning Studies 14 (1): 9-22. doi: 10.1080/09654310500339083

Douglas, E. J. 2013. "Reconstructing entrepreneurial intentions to identify predisposition for growth.” Journal of Business Venturing 28 (5): 633-651. doi: 10.1016/j.jbusvent.2012.07.005

Drinkwater, S. J., and N. C. O’Leary. 1997. "Unemployment in Wales: does language matter?” Regional Studies 31 (6): 583-591. doi: 10.1080/00343409750131712

Etzioni, A. 1987. "Entrepreneurship, adaptation and legitimation: a macro-behavior perspective.” Journal of Economic Behavior and Organization 8 (2): 175-189. doi: 10.1016/0167-2681(87)90002-3

Eurostat. 2009. 'High-technology' and 'knowledge based services' aggregations based on NACE Rev. 2. Luxemburg: Eurostat.

Evans, D. S., and L. S. Leighton. 1989. "Some empirical aspects of entrepreneurship." American Economic Review 79 (3): 519-535.

Felzensztein, C., E. Gimmon, and C. Aqueveque. 2013. "Entrepreneurship at the periphery: exploring framework conditions in core and peripheral locations.” Entrepreneurship Theory and Practice 37 (4): 815-835. doi: 10.1111/j.1540-6520.2012.00515.x

Findlay, A., C. Mason, D. Houston, D. McCollum, and R. Harrison. 2009. "Escalators, elevators and travelators: the occupational mobility of migrants to South-East England.” Journal of Ethnic and Migration Studies 35 (6): doi: 10.1080/13691830902957676

Forslid, R., and G. I. P. Ottaviano. 2003. “An analytically solvable core-periphery model.” Journal of Economic Geography 3 (3): 229-240. doi: 10.1093/jeg/3.3.229 
Fotopoulos, G., and H. Louri. 2000. "Location and survival of new entry." Small Business Economics 14 (4): 311-321. doi: 10.1023/A:1008180522759

Frankish, J. S., R. G. Roberts, and D. J. Storey. 2010. "Enterprise profiles in deprived areas: are they distinctive?” International Journal of Entrepreneurship and Small Business 9 (2): 127-142. doi: 10.1504/IJESB.2010.030616

Fritsch, M., U. Brixy, and O. Falck. 2006. "The effect of industry, region, and time on new business survival - a multi-dimensional analysis.” Review of Industrial Organisation 28 (3): 285-306. doi: 10.1007/s11151-006-0018-4

Fritsch, M., and M. Wyrwich. 2014. "The long persistence of regional levels of entrepreneurship: Germany, 1925-2005.” Regional Studies 48 (6): 955-973. doi: 10.1080/00343404.2013.816414

Fuzi, A. 2015. "Co-working spaces for promoting entrepreneurship in sparse regions: the case of South Wales.” Regional Studies, Regional Science 2 (1): 461-468. doi: 10.1080/21681376.2015.1072053

Ganotakis, P. 2012. "Founders' human capital and the performance of UK new technology based firms.” Small Business Economics 39 (2): 495-515. doi: 10.1007/s11187-0109309-0

Gardiner, B., R. Martin, P. Sunley, and P. Tyler. 2013. "Spatially unbalanced growth in the British economy." Journal of Economic Geography 13 (6): 889-928. doi: 10.1093/jeg/lbt003

Geroski, P. A., J. Mata, and P. Portugal. 2010. "Founding conditions and the survival of new firms.” Strategic Management Journal 31 (5): 510-529. doi: 10.1002/smj.823

Gibrat, R. 1931. Les inégalités économiques, Paris: Recueil Sirey.

Gicheva, D., and L. N. Link. 2013. "Leveraging entrepreneurship through private investments: does gender matter?” Small Business Economics 40 (2): 199-210. doi: 10.1007/s11187-011-9411-y

Gimeno, J., T. B. Folta, A. C. Cooper, and C. Y. Woo. 1997. "Survival of the fittest? Entrepreneurial human capital and the persistence of underperforming firms." Administrative Science Quarterly 42 (4): 750-783. doi: 10.2307/2393656

Gimmon, E., and J. Levie. 2010. "Founder's human capital, external investment, and the survival of new high-technology ventures.” Research Policy 39 (9): 1214-1226. doi: 10.1016/j.respol.2010.05.017

Gorton, M. 1999. "Spatial variations in markets served by UK-based small and medium-sized enterprises (SMEs).” Entrepreneurship and Regional Development 11 (1): 39-55. doi: $10.1080 / 089856299283281$

Gray, C. 1990. "Some economic - psychological considerations on the effects of the Enterprise Allowance Scheme (EAS).” Piccola Impresa 1: 111-124. doi: $10.1177 / 026624269100900410$

Gray, C. 2000. "Formality, intentionality, and planning: features of successful entrepreneurial SMEs in the future?” Paper presented at the ICSB World Conference, Brisbane, Australia: June 7-10.

Grenadier, S. R., and N. Wang. 2007. "Investment under uncertainty and time-inconsistent preferences.” Journal of Financial Economics 84 (1): 2-39. doi: 10.1016/j.jfineco.2006.01.002

Grilli, L. 2011. "When the going gets tough, do the tough get going? The pre-entry work experience of founders and high-tech survival during an industry crisis.” International Small Business Journal 29 (6): 626-647. doi: 10.1177/0266242610372845

Haapanen, M., and H. Tervo. 2009. "Self-employment duration in urban and rural locations." Applied Economics 41 (19): 2449-2461. doi: 10.1080/00036840802360278 
Hannan, M. T., and J. Freeman. 1977. "The population ecology of organizations.” American Journal of Sociology 82 (5): 929-964.

Hansen, B., and R. T. Hamilton. 2011. "Factors distinguishing small firm growers and nongrowers.” International Small Business Journal 29 (3): 278-294. doi: $10.1177 / 0266242610381846$

Hart, M., J. Levie, K. Bonner, and C-C. Drews. 2015. Global Entrepreneurship Monitor: United Kingdom 2014 Monitoring Report. Glasgow: University of Strathclyde.

Helmers, C., and M. Rogers. 2008. "Innovation and the survival of new firms across British regions.” Oxford University Department of Economics Discussion Paper Series \#416.

Henderson, A. D., M. E. Raynor, and M. Ahmed. 2012. "How long must a firm be great to rule out chance? Benchmarking sustained superior performance without being fooled by randomness." Strategic Management Journal 33 (4): 387-406. doi: 10.1002/smj.1943

Herslund, L. 2012. "The rural creative class: counterurbanisation and entrepreneurship in the Danish countryside.” Sociologia Ruralis 52 (2): 235-255. doi: 10.1111/j.14679523.2011.00560.x

Hindle, K., J. Yencken, and A. O’Connor. 2011. “An entrepreneurship policy framework for high-growth firms: navigating between policies for picking winners and market failure.” International Journal of Entrepreneurial Venturing 3 (4): 324-343. doi: 10.1504/IJEV.2011.043381

Holmes, T. J., and J. A. Schmitz. 1996. "Managerial tenure, business age, and small business turnover." Journal of Labour Economics 14 (1): 79-99.

Holtz-Eakin, D., D. Joulfaian, and H. S. Rosen. 1994. "Sticking it out: entrepreneurial survival and liquidity constraints.” Journal of Political Economy 102 (1): 53-75.

Honjo, Y., and N. Harada. 2006. "SME policy, financial structure and firm growth: evidence from Japan.” Small Business Economics 27 (4/5): 289-300. doi: 10.1007/s11187-0056703-0

Huggins, R., and P. Thompson. 2014. "Culture, entrepreneurship and uneven development: a spatial analysis.” Entrepreneurship and Regional Development, 26(9-10), 726-752. doi: 10.1080/08985626.2014.985740

Huggins, R., and P. Thompson. 2015. "Culture and place-based development: a socioeconomic analysis.” Regional Studies 49 (1): 130-159. doi: 10.1080/00343404.2014.889817

Huggins, R., and N. Williams. 2011. "Entrepreneurship and regional competitiveness: the role and progression of policy." Entrepreneurship and Regional Development 23 (9/10): 907-932. doi: 10.1080/08985626.2011.577818

Iammarino, S., and E. Marinelli. 2011. "Is the grass greener on the other side of the fence? Graduate mobility and job satisfaction in Italy.” Environment and Planning A 43 (11): 2761-2777. doi: 10.1068/a44126

Irvine, W., and A. R. Anderson. 2008. "ICT (information communication technology), peripherality and smaller hospitality businesses in Scotland.” International Journal of Entrepreneurial Behaviour and Research 14 (4): 200-218. doi: 10.1108/13552550810887381

Jack, S. L., and A. R. Anderson. 2002. "The effects of embeddedness on the entrepreneurial process.” Journal of Business Venturing 17 (5): 467-487. doi: 10.1016/S08839026(01)00076-3

Jones, M. K., and A. Henley. 2008. "Welsh economic performance: recent experience and future challenges.” Contemporary Wales 21 (1): 150-173. 
Jones, P., and A. Colwill. 2013. "Entrepreneurship education: an evaluation of the Young Enterprise Wales initiative." Education and Training 55 (8/9): 911-925. doi: 10.1108/ET-04-2013-0052

Jones-Evans, D. 2015. "Access to finance to SMEs at a regional level - the case of Finance Wales.” Venture Capital 17 (1-2): 27-41. doi: 10.1080/13691066.2015.1052624

Jones-Evans, D., P. Thompson, and C. Kwong. 2011. "Entrepreneurship amongst minority language speakers: the case of Wales.” Regional Studies 45 (2): 219-238. doi: 10.1080/00343400903241493

Jones-Evans, D., P. Thompson, and S. Hill. 2008. Global Entrepreneurship Monitor: 2007 Wales Executive Summary Report. Pontypridd: University of Glamorgan.

Jovanovic, B. 1982. "Selection and the evolution of industry.” Econometrica 50 (3): 649-670. doi: 10.2307/1912606

Kaufmann, D., and M. Malul. 2015. "The dynamic brain drain of entrepreneurs in peripheral regions.” European Planning Studies 23 (7): 1345-1356. doi: 10.1080/09654313.2014.929639

Keeble, D., P. L. Owens, and C. Thompson. 1992. "Regional accessibility and economic potential in the European Community." Regional Studies 16 (6): 419-432. doi: $10.1080 / 09595238200185421$

Keeble, D., and P. Tyler. 1995. "Enterprising behaviour and the urban-rural shift.” Urban Studies 32 (6): 975-997. doi: 10.1080/00420989550012753

Kelly, R., C. Mulvey, and P. E. T. Lewis. 2002. "Self-employment programs and outcomes for disadvantaged jobseekers.” Australian Bulletin of Labour 28 (4): 247-271.

Kibler, E., T. Kautonen, and M. Fink. 2014. "Regional social legitimacy of entrepreneurship: implications for entrepreneurial intention and start-up behaviour.” Regional Studies 48 (6): 995-1015. doi: 10.1080/00343404.2013.851373

Kim, G. 2007. "The analysis of self-employment levels over the life-cycle.” Quarterly Review of Economics and Finance 47 (3): 397-410. doi: 10.1016/j.qref.2006.06.004

Kosanovich, W. T., H. Fleck, B. Yost, W. Armon, and S. Siliezar. 2001. Comprehensive Assessment of Self-Employment Assistance Programs - Final Report. Arlington, VA: DTI Associates.

Koster, S., and A. van Stel. 2014. "The relationship between start-ups, market mobility and employment growth: an empirical analysis for Dutch regions.” Papers in Regional Science 93 (1): 203- 218. doi:10.1111/pirs.12000

Krugman, P. 1991. "Increasing returns and economic geography." Journal of Political Economy 99 (3): 483-499.

Kwong, C. and P. Thompson. 2016. "The when and why: student entrepreneurial aspirations.” Journal of Small Business Management 54 (1): 299-318. doi: 10.1111/jsbm.12146

Lawton Smith, H., J. Glasson, S. Romeo, R. Waters, and A. Chadwick. 2013. "Entrepreneurial regions: evidence from Oxfordshire and Cambridgeshire." Social Science Information 52 (4): 653-673. doi: 10.1177/0539018413499978

Lee, H., D. Kelley, J. Lee, and S. Lee. 2012. "SME survival: the impact of internationalization, technology resources, and alliances.” Journal of Small Business Management 50 (1): 1-19. doi: 10.1111/j.1540-627X.2011.00341.X

Lee, S. Y., R. Florida, and Z. J. Acs. 2004. "Creativity and entrepreneurship: a regional analysis of new firm formation.” Regional Studies 38 (8): 879-891. doi: 10.1080/0034340042000280910

Lejpras, A., and A. Stephan. 2011. "Locational conditions, cooperation, and innovativeness: evidence from research and company spin-offs.” The Annals of Regional Science 46 (3): 543-575. doi: 10.1007/s00168-009-0356-x 
Lévesque, M., and M. Minniti. 2006. "The effect of aging on entrepreneurial behavior." Journal of Business Venturing 21 (2): 177-194. doi: 10.1016/j.jbusvent.2005.04.003

Levie, J., and M. Hart. 2013. Global Entrepreneurship Monitor: United Kingdom 2012 Monitoring Report. Glasgow: University of Strathclyde Business School/Aston Business School.

Levinthal, D. 1991. "Random walks and organizational mortality." Administrative Science Quarterly 36 (3): 397-420. doi: 10.2307/2393202

Maki, K., and T. Pukkinen. 2000. "Barriers to growth and employment in Finnish small enterprises.” Paper presented at the ICSB World Conference, Brisbane, Australia: June.

Malecki, E. J. 1990. "New formation in the USA: corporate structure, venture capital, and local environment.” Entrepreneurship and Regional Development 2 (3): 247-265. doi: $10.1080 / 08985629000000016$

Malul, M. 2015. "The process of brain drain in peripheral regions.” Applied Economic Letters 22 (17): 1419-1423. doi: 10.1080/13504851.2015.1037429

Manning, A., and J. Swaffield. 2008. "The gender pay gap in early-career wage growth." Economic Journal 113 (530): 983-1024. doi: 10.1111/j.1468-0297.2008.02158.x

Martin, B. R. 2012a. "Are universities and university research under threat? Towards an evolutionary model of university speciation." Cambridge Journal of Economics 36 (3): 543-565. doi: 10.1093/cje/bes006

Martin, R. 2012b. "Regional economic resilience, hysteresis and recessionary shocks." Journal of Economic Geography 12 (1): 1-32. doi: 10.1093/jeg/lbr019

Mason, C. M., and R. Brown. 2013. "Creating good public policy to support high-growth firms.” Small Business Economics 40 (2): 211-225. doi: 10.1007/s11187-011-9369-9

McAdam, R., R. Reid, and M. Shevlin. 2014. "Determinants for innovation and implementation at SME and inter SME levels within peripheral regions." International Journal of Entrepreneurial Behaviour and Research 20 (1): 66-90. doi: 10.1108/IJEBR-02-2012-0025

Millán, J. M., E. Congregado, and C. Román. 2012. "Determinants of self-employment survival in Europe.” Small Business Economics 38 (2): 231-258. doi: 10.1007/s11187010-9260-0

Millán, J. M., E. Congregado, C. Román, M. van Praag, and A. van Stel. 2014. "The value of an educated population for an individual's entrepreneurship success." Journal of Business Venturing 29 (5): 612-632. doi: 10.1016/j.jbusvent.2013.09.003

Mochrie, R., L. Galloway, and E. Donnelly. 2006. "Attitudes to growth and experience of growth among Scottish SMEs.” International Journal of Entrepreneurial Behaviour and Research 12 (1): 7-20. doi: 10.1108/13552550610644454

Moen, Ø., A. G. Heggeseth, and O. Lome. 2016. "The positive effect of motivation and international growth orientation on SME growth.” Journal of Small Business Management 54 (2): 659-678. doi: 10.1111/jsbm.12163

Morgan, K., and A. Price. 2011. The Collective Entrepreneur: Social Enterprise and the Smart State. Cardiff: Cymru Group.

Morin, R. A., and A. F. Suarez. 1983. "Risk aversion revisited.” Journal of Finance 38 (4): 1201-1216. doi: $10.2307 / 2328020$

Morrison, A., J. Breen, and S. Ali. 2003. "Small business growth: intention, ability, and opportunity." Journal of Small Business Management 41 (4): 417-425. doi: 10.1111/1540-627X.00092

Motwani, J., N. M. Levenburg, T. V. Schwarz, and C. Blankson. 2006. "Succession planning in SMEs: an empirical analysis.” International Small Business Journal 24 (5): 471495. doi: 10.1177/0266242606067270 
Mueller, E., and J. N. Morgan. 1962. "Location decisions of manufacturers." American Economic Review 52 (2): 204-217.

Mueller, S. L., and M. Conway Data-on. 2013. "A cross cultural study of gender-role orientation and entrepreneurial self-efficacy." International Entrepreneurship and Management Journal 9 (1): 1-20. doi: 10.1007/s11365-011-0187-y

Murphy, L., R. Huggins, and P. Thompson. 2015. "Social capital and innovation: a comparative analysis of regional policies.” Environment and Planning C: Government and Policy. doi: 10.1177/0263774X15597448

North, D., R. Leigh, and D. Smallbone. 1992. “A comparison of surviving and non-surviving small and medium sized manufacturing firms in London during the 1980s." in Small Enterprise Development: Policy and Practice in Action, edited by K. Caley, E. Chell, F. Chittenden, and C. Mason, 12-27. London: Paul Chapman Publishing.

North, D., and D. Smallbone. 2000. "Innovation activity in SMEs and rural economic development: some evidence from England.” European Planning Studies 8 (1): 87106. doi: 10.1080/096543100110947

North, D., and D. Smallbone. 2006. “Developing entrepreneurship and enterprise in Europe's peripheral rural areas: some issues facing policy-makers.” European Planning Studies 14 (1): 41-60. doi: 10.1080/09654310500339125

North, D., D. Smallbone, F. Lyon, and G. Potts. 2003. Business-led regeneration of deprived areas: a review of the evidence base - Office of the Deputy Prime Minister Research Report 5. London: Office of Deputy Prime Minister.

Office for National Statistics (ONS). 2004. Rural and Urban Classification 2004. London: HMSO.

Office for National Statistics (ONS). 2011. Business Demography - 2010: Enterprise Births, Deaths, and Survivals. Newport: Office for National Statistics.

Pe'er, A., I. Vertinsky, and T. Keil. 2016. "Growth and survival: the moderating effects of local agglomeration and local market structure.” Strategic Management Journal 37 (3): 541-564. doi: 10.1002/smj.2331

Philpott, K., L. Dooley, C. O’Reilly, and G. Lupton. 2011. “The entrepreneurial university: examining the underlying academic tensions.” Technovation 31 (4): 161-170. doi: 10.1016/j.technovation.2010.12.003

Piergiovanni, R., M. A. Carree, and E. Santarelli. 2012. "Creative industries, new business formation, and regional economic growth.” Small Business Economics 39 (3): 539560. doi: 10.1007/s11187-011-9329-4

Politis, D. 2005. "The process of entrepreneurial learning, a conceptual framework." Entrepreneurship Theory and Practice 29 (4): 399-424. doi: 10.1111/j.15406520.2005.00091.x

Politis, D. 2008. "Does prior start-up experience matter for entrepreneurs' learning?: a comparison between novice and habitual entrepreneurs.” Journal of Small Business and Enterprise Development 15 (3): 472-489. doi: 10.1108/14626000810892292

Quadrini, V. 1999. "The importance of entrepreneurship for wealth concentration and mobility." Review of Income and Wealth 45 (1): 1-19. doi: 10.1111/j.14754991.1999.tb00309.x

Rae, D. 2010. "Universities and enterprise education: responding to the challenges of the new era.” Journal of Small Business and Enterprise Development 17(4): 591-606. doi: 10.1108/14626001011088741

Ramos-Rodríguez, A.-R., J.-A. Medina-Garrido, J.-D. Lorenzo-Gómez, and J. Ruiz-Navarro. 2010. "What you know or who you know? The role of intellectual and social capital in opportunity recognition.” International Small Business Journal 28 (6): 566-582. doi: $10.1177 / 0266242610369753$ 
Raspe, O., and F. van Oort. 2011. "Growth of new firms and spatially bounded knowledge externalities.” The Annals of Regional Science 46 (3): 495-518. doi: 10.1007/s00168009-0357-9

Rauch, A., and S. A. Rijsdijk. 2013. "The Effects of General and Specific Human Capital on Long-Term Growth and Failure of Newly Founded Businesses.” Entrepreneurship Theory and Practice 37 (4): 923-941. doi: 10.1111/j.1540-6520.2011.00487.x

Reid, G. C. 1991. "Staying in business.” International Journal of Industrial Organisation 9 (4): 545-556. doi: 10.1016/0167-7187(91)90064-R

Reid, G. C., and J. A. Smith. 2000. "What Makes a New Business Start-Up Successful?” Small Business Economics 14 (3): 165-182. doi: 10.1023/A:1008168226739

Renski, H. 2008. "New firm entry, survival, and growth in the United States: A comparison of urban, suburban, and rural areas." Journal of the American Planning Association 75 (1): 60-77. doi: 10.1080/01944360802558424

Renski, H. 2011. "External economies of localization, urbanization and industrial diversity and new firm survival.” Papers in Regional Science 90 (3): 473-503. doi: 10.1111/j.1435-5957.2010.00325.x

Renski, H. 2015. "Externalities or experience? Localization economies and start-up business survival.” Growth and Change 46 (3): 458-480. doi: 10.1111/grow.12099

Rérat, P. 2014. "Highly qualified rural youth: why do young graduates return to their home region?” Children's Geographies 12 (1): 70-86. doi: 10.1080/14733285.2013.850849

Rerup, C. 2005. "Learning from past experience: footnotes on mindfulness and habitual entrepreneurship." Scandinavian Journal of Management 21 (4): 451-472. doi: 10.1016/j.scaman.2005.09.010

Rhisiart, M., and D. Jones-Evans. 2016. "The impact of foresight on entrepreneurship: the Wales 2010 case study.” Technological Forecasting and Social Change 102: 112-119. doi: 10.1016/j.techfore.2015.03.010

Rotar, L. J. 2014. "Youth unemployment and entrepreneurship.” Ekonomika 60 (4): 43-56.

Rouse, J., and D. Jayawarna. 2006. "The financing of disadvantaged entrepreneurs: are enterprise programmes overcoming the finance gap?” International Journal of Entrepreneurial Behaviour and Research 12 (6): 388-400. doi: 10.1108/13552550610710162

Santarelli, E., M. Carree, and I. Verheul. 2009. "Unemployment and firm entry and exit: an update on a controversial relationship." Regional Studies 43 (8): 1061-1073. doi: 10.1080/00343400801968361

Santarelli, E., and M. Vivarelli. 2007. "Entrepreneurship and the process of firms' entry, survival and growth." Industrial and Corporate Change 16 (3): 455-488. doi: 10.1093/icc/dtm010

Sapienza, H. J., E. Autio, G. George, and S. A. Zahra. 2006. “A capabilities perspective on the effects of early internationalization on firm survival and growth." Academy of Management Review 31 (4): 914-933. doi: 10.5465/AMR.2006.22527465

Saridakis, G., J. Mole, and D. J. Storey. 2008. "New small firm survival in England." Empirica 35 (1): 25-39. doi: 10.1007/s10663-007-9049-9

Shane, S. 2009. "Why encouraging more people to become entrepreneurs is bad public policy.” Small Business Economics 33 (2):141-149. doi: 10.1007/s11187-009-9215-5

Simon, M., S. M. Houghton, and K. Aquino. 2000. "Cognitive biases, risk perception, and venture formation: how individuals decide to start companies.” Journal of Business Venturing 15 (2): 113-134. doi: 10.1016/S0883-9026(98)00003-2

Singh, J. V., and C. L. Lumsden. 1990. "Theory and research in organizational ecology.” Annual Review of Sociology 16 (1): 161-195. 
Skuras, D., K. Tsegenidi, and K. Tsekouras. 2008. "Product innovation and the decision to invest in fixed capital assets: evidence from an SME survey in six European Union member states." Research Policy 37 (10): 1778-1789. doi: 10.1016/j.respol.2008.08.013

Smallbone, D., R. Leigh, and D. North. 1995. "The characteristics and strategies of high growth SMEs.” International Journal of Entrepreneurial Behaviour and Research 1 (3): 44-62. doi: 10.1108/13552559510100657

Sorensen, O., and P. G. Audia. 2000. "The social structure of entrepreneurial activity: geographical concentration of footwear production in the United States 1940-1989.” American Journal of Sociology 106 (2): 224-262. doi: 10.1086/316962

Starr, J. A., and W. D. Bygrave. 1992. "The second time around: the outcomes, assets, and liabilities of prior start-up experience.” In International Perspectives on Entrepreneurship Research, edited by S. Birley, and I. MacMillan, 340-363. Amsterdam: North Holland.

Stearns, T. M., N. M. Carter, and P. Reynolds. 1995. "New firm survival: industry, strategy, and location." Journal of Business Venturing 10 (1): 23-42. doi: 10.1016/08839026(94)00016-N

Stephan, A. 2011. "Locational conditions and firm performance: introduction to the special issue.” The Annals of Regional Science 46 (3): 487-494. doi: 10.1007/s00168-0090358-8

Stephens, H. M., and M. D. Partridge. 2011. "Do entrepreneurs enhance economic growth in lagging regions?” Growth and Change 42 (4): 431-465. doi: 10.1111/j.14682257.2011.00563.x

Stephens, H. M., M. D. Partridge, and A. Faggian. 2013. "Innovation, entrepreneurship and economic growth in lagging regions.” Journal of Regional Science 53 (5): 778-812. doi: $10.1111 /$ jors. 12019

Stuart, T., and O. Sorenson. 2003. "The geography of opportunity: spatial heterogeneity in founding rates and the performance of biotechnology firms.” Research Policy 32 (2): 229-253. doi: 10.1016/S0048-7333(02)00098-7

Taylor, M. P. 1996. "Earnings, independence or unemployment: why become selfemployed?” Oxford Bulletin of Economics and Statistics 58 (2): 253-266. doi: 10.1111/j.1468-0084.1996.mp58002003.x

Taylor, M. P. 1999. "Survival of the fittest? An analysis of self-employment duration in Britain.” Economic Journal 109 (454): C140-C155. doi: 10.1111/1468-0297.00422

Thompson, P., D. Jones-Evans, and C. Kwong. 2012. "Entrepreneurship in deprived urban communities: the case of Wales." Entrepreneurship Research Journal 2 (1). doi: 10.2202/2157-5665.1033

Tödtling, F., and M. Trippl. 2005. "One size fits all? Towards a differentiated regional innovation policy approach.” Research Policy 34 (8): 1203-1219. doi: 10.1016/j.respol.2005.01.018

Townroe, P., and K. Mallalieu. 1993. "Founding a new business in the countryside." In Small Firms in Urban and Rural Locations, edited by J. Curran, and D. J. Storey, 17-53. London: Routledge.

Unger, J. M., A. Rauch, M. Frese, and N. Rosenbusch. 2011. "Human capital and entrepreneurial success: a meta-analytical review.” Journal of Business Venturing 26 (3): 341-358. doi: 10.1016/j.jbusvent.2009.09.004

Vaessen, P., and D. Keeble. 1995. "Growth-oriented SMEs in unfavourable regional environments.” Regional Studies 29 (6): 489-505. 10.1080/00343409512331349133 
Van der Sluis, J., M. van Praag, and W. Vijverberg. 2008. "Education and entrepreneurship selection and performance: a review of the empirical literature." Journal of Economic Surveys 22 (5): 795-841. doi: 10.1111/j.1467-6419.2008.00550.x

Van Looy, B., P. Landoni, J. Callaert, B. van Pottelsberghe, E. Sapsalis, and K. Debackere. 2011. "Entrepreneurial effectiveness of European universities: an empirical assessment of antecedents and trade-offs." Research Policy 40 (4): 553-564. doi: 10.1016/j.respol.2011.02.001

van Witteloostuijn, A. 1998. "Bridging behavioral and economic theories of decline: organizational inertia, strategic competition and chronic failure." Management Science 44 (4): 502-519.

Vernon, R. 1960. Metropolis 1985: Interpretation of the findings of the New York metropolitan region study. Cambridge, MA: Harvard University Press.

Warren-Smith, I., and C. Jackson. 2004. "Women creating wealth through rural enterprise." International Journal of Entrepreneurial Behaviour and Research 10 (6): 369-383. doi: 10.1108/13552550410564707

Wennberg, K., and G. Lindqvist. 2010. "The effect of clusters on the survival and performance of new firms." Small Business Economics 34 (3): 221-241. doi: 10.1007/s11187-008-9123-0

Wennberg, K., J. Wiklund, D. R. DeTienne, and M. S. Cardon. 2010. "Reconceptualizing entrepreneurial exit: divergent exit routes and their drivers." Journal of Business Venturing 25 (4): 361-375. doi: 10.1016/j.jbusvent.2009.01.001

Weterings, A. and O. Marsili. 2015. "Spatial concentration of industries and new firm exits: does this relationship differ between exits by closure and by M\&A?” Regional Studies 49 (1): 44-58. doi: 10.1080/00343404.2012.726708

Wiklund, J., and D. Shepherd. 2003. "Aspiring for, and achieving growth: the moderating role of resources and opportunities.” Journal of Management Studies 40 (8): 19191941. doi: 10.1046/j.1467-6486.2003.00406.x.

Williams, D. R. 2004. "Youth self employment: its nature and consequences." Small Business Economics 23 (4): 323-336. doi: 10.1023/B:SBEJ.0000032035.30738.01

Williams, N., and C. C. Williams. 2011. "Tackling barriers to entrepreneurship in a deprived urban neighbourhood.” Local Economy 26 (1): 30-42. doi: $10.1177 / 0269094210391166$

Williams, N., and C. C. Williams. 2014. "Beyond necessity versus opportunity entrepreneurship: some lessons from English deprived urban neighbourhoods." International Entrepreneurship Management Journal 10 (1): 23-40. doi: 10.1007/s11365-011-0190-3.

Williams, R., G. P. Packham, B. C. Thomas, and P. Thompson. 2009. "Small business sales growth and internationalization links to website functions in the United Kingdom." In E-Commerce Adoption and Small Business in the Global Marketplace: Tools for Optimization, edited by B. C. Thomas, and G. Simmons, 139-173. Hershey, PA: IGI Global.

Yoo, S-J., N. G. Mackenzie, and D. Jones-Evans. 2012. "Public sector support and technology-based SMEs in peripheral areas - the case of North Wales.” Journal of Enterprising Culture 20 (1): 83-104. doi: 10.1142/S0218495812500045 
Table 1: Percentage of firms surviving

\begin{tabular}{|c|c|c|c|c|c|c|}
\hline & & $\begin{array}{l}\text { Percentage } \\
\text { Surviving }\end{array}$ & $N$ & chi-square & [d.f.] & (p-value) \\
\hline \multirow{2}{*}{$\begin{array}{l}\text { General Growth } \\
\text { Motivation }\end{array}$} & $\begin{array}{l}\text { Non-Growth } \\
\text { Orientated }\end{array}$ & $47.8 \%$ & 452 & $13.708^{\star \star \star \star}$ & [1] & $(0.000)$ \\
\hline & $\begin{array}{l}\text { Growth } \\
\text { Orientated }\end{array}$ & $58.3 \%$ & 973 & & & \\
\hline \multirow{3}{*}{ Geographical Scope } & $\begin{array}{l}\text { Main Market } \\
\text { Local }\end{array}$ & $54.1 \%$ & 911 & 0.727 & [2] & $(0.695)$ \\
\hline & $\begin{array}{l}\text { Main Market } \\
\text { Regional }\end{array}$ & $56.8 \%$ & 213 & & & \\
\hline & $\begin{array}{c}\text { Main Market } \\
\text { National or wider }\end{array}$ & $56.1 \%$ & 301 & & & \\
\hline \multirow{3}{*}{$\begin{array}{l}\text { Entrepreneur } \\
\text { Experience }\end{array}$} & Under 35 years & $54.1 \%$ & 1181 & 1.969 & [1] & $(0.161)$ \\
\hline & 35 to 49 years & $59.0 \%$ & 244 & & & \\
\hline & 50 years or older & $51.9 \%$ & 499 & & & \\
\hline \multirow{3}{*}{$\begin{array}{l}\text { Entrepreneurs' } \\
\text { Education }\end{array}$} & $\begin{array}{c}\text { No Formal } \\
\text { Qualifications }\end{array}$ & $51.2 \%$ & 291 & 2.078 & [2] & $(0.354)$ \\
\hline & $\begin{array}{c}\text { Secondary } \\
\text { Qualifications }\end{array}$ & $55.8 \%$ & 638 & & & \\
\hline & $\begin{array}{l}\text { Graduate or } \\
\text { higher }\end{array}$ & $56.0 \%$ & 496 & & & \\
\hline \multirow{4}{*}{ Prior Workstatus } & Employed & $54.1 \%$ & 1013 & $15.944^{\star \star \star}$ & [3] & $(0.001)$ \\
\hline & $\begin{array}{l}\text { Education or } \\
\text { Training }\end{array}$ & $66.0 \%$ & 100 & & & \\
\hline & Out of Work & $36.8 \%$ & 68 & & & \\
\hline & Self-employed & $59.0 \%$ & 244 & & & \\
\hline \multirow{3}{*}{ Agglomeration } & Urban & $53.0 \%$ & 773 & 2.659 & [2] & $(0.265)$ \\
\hline & Town or Fringe & $55.9 \%$ & 186 & & & \\
\hline & Village or Hamlet & $57.7 \%$ & 466 & & & \\
\hline \multirow{2}{*}{ Gross Value Added } & $\begin{array}{l}\text { Below Median } \\
\text { Growth }\end{array}$ & $53.2 \%$ & 616 & 1.268 & [1] & $(0.260)$ \\
\hline & $\begin{array}{l}\text { Above Median } \\
\text { Growth }\end{array}$ & $56.2 \%$ & 809 & & & \\
\hline \multirow[t]{2}{*}{ Unemployment } & $\begin{array}{l}\text { Below Median } \\
\text { Unemployment } \\
\text { Change } \\
\text { Above Median }\end{array}$ & $57.4 \%$ & 673 & $2.987^{\star}$ & [1] & $(0.084)$ \\
\hline & $\begin{array}{l}\text { Unemployment } \\
\text { Change }\end{array}$ & $52.8 \%$ & 752 & & & \\
\hline \multirow{2}{*}{ Industry Density } & $\begin{array}{l}\text { Below Median } \\
\text { Industry Density }\end{array}$ & $53.3 \%$ & 707 & 1.494 & [1] & $(0.222)$ \\
\hline & $\begin{array}{l}\text { Above Median } \\
\text { Industry Density }\end{array}$ & $56.5 \%$ & 718 & & & \\
\hline
\end{tabular}

Notes: ${ }^{* * *}$ significant at 1 percent level; ${ }^{* *}$ significant at 5 percent level; * significant at 10 percent level 
Table 1: Continued

\begin{tabular}{|c|c|c|c|c|c|c|}
\hline & & $\begin{array}{c}\text { Percentage } \\
\text { Surviving }\end{array}$ & $N$ & chi-square & [d.f.] & (p-value) \\
\hline \multirow{4}{*}{ Industry } & Manufacturing & $54.3 \%$ & 254 & 1.105 & [3] & $(0.776)$ \\
\hline & Construction & $52.5 \%$ & 202 & & & \\
\hline & Services & $55.2 \%$ & 833 & & & \\
\hline & Other Industry & $58.1 \%$ & 136 & & & \\
\hline \multirow{2}{*}{$\begin{array}{l}\text { Knowledge } \\
\text { Intensity }\end{array}$} & $\begin{array}{l}\text { Less Knowledge } \\
\text { Intensive }\end{array}$ & $55.9 \%$ & 1095 & 1.699 & [1] & (0.192) \\
\hline & $\begin{array}{l}\text { Knowledge } \\
\text { Intensive }\end{array}$ & $51.8 \%$ & 330 & & & \\
\hline \multirow{3}{*}{ Legal Status } & Limited Liability & $59.7 \%$ & 221 & $27.200^{\star \star \star}$ & [2] & $(0.000)$ \\
\hline & Partnerships & $65.0 \%$ & 360 & & & \\
\hline & Sole Trader & $49.4 \%$ & 844 & & & \\
\hline \multirow[b]{2}{*}{ Size of Firm } & $\begin{array}{c}\text { Micro (less than } 10 \\
\text { employees) }\end{array}$ & $53.2 \%$ & 1279 & $15.992^{\star \star *}$ & [1] & $(0.000)$ \\
\hline & $\begin{array}{l}\text { Small or Medium } \\
\text { (10 to } 249 \\
\text { employees) }\end{array}$ & $70.5 \%$ & 146 & & & \\
\hline \multirow{3}{*}{ Gender } & Male & $56.5 \%$ & 1030 & $3.641^{*}$ & [1] & $(0.056)$ \\
\hline & Female & $50.9 \%$ & 395 & & & \\
\hline & All & $55.1 \%$ & 1438 & & & \\
\hline
\end{tabular}

Notes: ${ }^{* * *}$ significant at 1 percent level; ${ }^{* *}$ significant at 5 percent level; $*$ significant at 10 percent level 
Table 2: Spearman rank correlations

\begin{tabular}{|c|c|c|c|c|c|c|c|c|c|c|c|c|c|}
\hline & $\begin{array}{c}1 . \\
\text { Survival } \\
\end{array}$ & 2 & 3 & 4 & 5 & 6 & 7 & 8 & 9 & 10 & 11 & 12 & 13 \\
\hline $\begin{array}{l}\text { 2. General Growth } \\
\text { Motivation }\end{array}$ & $\begin{array}{l}0.098^{\star \star \star *} \\
(0.000)\end{array}$ & & & & & & & & & & & & \\
\hline $\begin{array}{l}\text { 3. Geographical } \\
\text { Market Orientation }\end{array}$ & $\begin{array}{c}0.021 \\
(0.432)\end{array}$ & $\begin{array}{l}0.175^{\star \star *} \\
(0.000)\end{array}$ & & & & & & & & & & & \\
\hline 4. Entrepreneur Age & $\begin{array}{l}-0.016 \\
(0.557)\end{array}$ & $\begin{array}{c}-0.124^{\star \star \star} \\
(0.000)\end{array}$ & $\begin{array}{c}0.043 \\
(0.109)\end{array}$ & & & & & & & & & & \\
\hline $\begin{array}{l}\text { 5. Entrepreneur } \\
\text { Education }\end{array}$ & $\begin{array}{c}0.030 \\
(0.255)\end{array}$ & $\begin{array}{l}0.127^{\star \star \star} \\
(0.000)\end{array}$ & $\begin{array}{l}0.181^{\star * *} \\
(0.000)\end{array}$ & $\begin{array}{l}-0.082^{\star \star \star} \\
(0.002)\end{array}$ & & & & & & & & & \\
\hline $\begin{array}{l}\text { 6. Prior Self- } \\
\text { Employment }\end{array}$ & $\begin{array}{c}0.037 \\
(0.161)\end{array}$ & $\begin{array}{c}0.038 \\
(0.156)\end{array}$ & $\begin{array}{c}0.044 \\
(0.100)\end{array}$ & $\begin{array}{l}0.097^{\star \star \star \star} \\
(0.000)\end{array}$ & $\begin{array}{l}-0.048^{\star} \\
(0.071)\end{array}$ & & & & & & & & \\
\hline 7. Agglomeration & $\begin{array}{l}-0.043 \\
(0.103)\end{array}$ & $\begin{array}{l}0.083^{\star * *} \\
(0.002)\end{array}$ & $\begin{array}{c}-0.091^{* * *} \\
(0.001)\end{array}$ & $\begin{array}{l}-0.096^{\star \star \star} \\
(0.000)\end{array}$ & $\begin{array}{c}0.010 \\
(0.701)\end{array}$ & $\begin{array}{l}-0.062^{\star *} \\
(0.019)\end{array}$ & & & & & & & \\
\hline 8. GVA Growth & $\begin{array}{c}0.038 \\
(0.154)\end{array}$ & $\begin{array}{l}-0.026 \\
(0.327)\end{array}$ & $\begin{array}{c}0.007 \\
(0.802)\end{array}$ & $\begin{array}{l}-0.023 \\
(0.378)\end{array}$ & $\begin{array}{l}0.054^{\star *} \\
(0.041)\end{array}$ & $\begin{array}{l}-0.070^{\star \star \star} \\
(0.008)\end{array}$ & $\begin{array}{l}0.240^{\star \star \star} \\
(0.000)\end{array}$ & & & & & & \\
\hline $\begin{array}{l}\text { 9. Unemployment } \\
\text { Change }\end{array}$ & $\begin{array}{l}-0.047^{\star} \\
(0.074)\end{array}$ & $\begin{array}{l}0.056^{\star \star} \\
(0.034)\end{array}$ & $\begin{array}{c}0.028 \\
(0.295)\end{array}$ & $\begin{array}{l}-0.028 \\
(0.289)\end{array}$ & $\begin{array}{l}-0.005 \\
(0.837)\end{array}$ & $\begin{array}{l}-0.065^{\star \star} \\
(0.015)\end{array}$ & $\begin{array}{l}0.377^{\star \star \star} \\
(0.000)\end{array}$ & $\begin{array}{c}0.314^{\star \star \star} \\
(0.000)\end{array}$ & & & & & \\
\hline 10. Industry Density & $\begin{array}{c}0.019 \\
(0.473)\end{array}$ & $\begin{array}{l}-0.065^{\star \star} \\
(0.014)\end{array}$ & $\begin{array}{l}-0.053^{\star \star} \\
(0.045)\end{array}$ & $\begin{array}{c}0.011 \\
(0.667)\end{array}$ & $\begin{array}{c}-0.057^{\star \star} \\
(0.032)\end{array}$ & $\begin{array}{l}0.063^{\star \star} \\
(0.017)\end{array}$ & $\begin{array}{l}-0.066^{\star \star} \\
(0.012)\end{array}$ & $\begin{array}{c}0.028 \\
(0.283)\end{array}$ & $\begin{array}{l}-0.103^{\star \star \star} \\
(0.000)\end{array}$ & & & & \\
\hline $\begin{array}{l}\text { 11. Industry } \\
\text { Knowledge Intensity }\end{array}$ & $\begin{array}{l}-0.035 \\
(0.193)\end{array}$ & $\begin{array}{l}0.099^{\star \star *} \\
(0.000)\end{array}$ & $\begin{array}{l}0.159 * \star * \\
(0.000)\end{array}$ & $\begin{array}{c}0.032 \\
(0.225)\end{array}$ & $\begin{array}{l}0.288^{\star * \star *} \\
(0.000)\end{array}$ & $\begin{array}{l}-0.042 \\
(0.113)\end{array}$ & $\begin{array}{l}0.075^{\star \star \star} \\
(0.004)\end{array}$ & $\begin{array}{l}0.069 * \star \star \\
(0.009)\end{array}$ & $\begin{array}{c}0.037 \\
(0.160)\end{array}$ & $\begin{array}{l}-0.124^{\star * *} \\
(0.000)\end{array}$ & & & \\
\hline 12. Legal Status & $\begin{array}{l}0.122^{\star \star \star} \\
(0.000)\end{array}$ & $\begin{array}{l}0.131^{\star \star \star} \\
(0.000)\end{array}$ & $\begin{array}{c}0.258^{\star \star *} \\
(0.000)\end{array}$ & $\begin{array}{c}0.043 \\
(0.108)\end{array}$ & $\begin{array}{c}0.116^{\star \star \star} \\
(0.000)\end{array}$ & $\begin{array}{l}0.065^{\star \star} \\
(0.014)\end{array}$ & $\begin{array}{c}0.013 \\
(0.628)\end{array}$ & $\begin{array}{c}0.013 \\
(0.625)\end{array}$ & $\begin{array}{l}0.048^{*} \\
(0.070)\end{array}$ & $\begin{array}{c}0.012 \\
(0.643)\end{array}$ & $\begin{array}{c}0.012 \\
(0.638)\end{array}$ & & \\
\hline 13. Firm Size & $\begin{array}{c}0.106^{\star \star \star} \\
(0.000)\end{array}$ & $\begin{array}{c}0.121^{\star \star \star} \\
(0.000)\end{array}$ & $\begin{array}{c}0.141^{\star \star *} \\
(0.000)\end{array}$ & $\begin{array}{c}0.003 \\
(0.910)\end{array}$ & $\begin{array}{c}0.078^{\star \star \star} \\
(0.003)\end{array}$ & $\begin{array}{c}0.000 \\
(1.000)\end{array}$ & $\begin{array}{c}0.076^{\star \star \star} \\
(0.004)\end{array}$ & $\begin{array}{c}0.033 \\
(0.215)\end{array}$ & $\begin{array}{c}0.070^{\star \star \star} \\
(0.008)\end{array}$ & $\begin{array}{c}0.006 \\
(0.813)\end{array}$ & $\begin{array}{l}0.061^{\star *} \\
(0.020)\end{array}$ & $\begin{array}{c}0.296^{\star \star \star} \\
(0.000)\end{array}$ & \\
\hline 14. Male & $\begin{array}{c}0.051^{*} \\
(0.056)\end{array}$ & $\begin{array}{l}-0.008 \\
(0.771)\end{array}$ & $\begin{array}{c}0.039 \\
(0.146)\end{array}$ & $\begin{array}{c}0.100^{\star * * *} \\
(0.000)\end{array}$ & $\begin{array}{l}-0.017 \\
(0.529)\end{array}$ & $\begin{array}{c}-0.014 \\
(0.597)\end{array}$ & $\begin{array}{l}0.068^{\star \star} \\
(0.010)\end{array}$ & $\begin{array}{c}0.011 \\
(0.679)\end{array}$ & $\begin{array}{c}0.028 \\
(0.295)\end{array}$ & $\begin{array}{c}-0.042 \\
(0.115)\end{array}$ & $\begin{array}{l}-0.009 \\
(0.723)\end{array}$ & $\begin{array}{c}0.020 \\
(0.443)\end{array}$ & $\begin{array}{l}0.064^{\star *} \\
(0.015)\end{array}$ \\
\hline
\end{tabular}

Notes: p-values in parentheses; *** significant at 1 percent level; ${ }^{* *}$ significant at 5 percent level; * significant at 10 percent level 
Table 3: Likelihood ratio tests of factor influences on firm survival

\begin{tabular}{lcccc}
\hline & & Full & Micro & Small \\
& & Sample & Firms & Firms \\
\hline \multirow{3}{*}{ Growth Motivation } & LR-test & $12.670^{* * *}$ & $13.690^{* * *}$ & 5.560 \\
& {$[$ d.f] } & {$[3]$} & {$[3]$} & {$[3]$} \\
& (p-value) & $(0.005)$ & $(0.003)$ & $(0.135)$ \\
& LR-test & $10.200^{* *}$ & $8.300^{*}$ & $12.160^{* *}$ \\
& {$[$ d.f] } & {$[4]$} & {$[4]$} & {$[4]$} \\
& (p-value) & $(0.037)$ & $(0.081)$ & $(0.016)$ \\
Business Ownership Specific Human Human Capital & LR-test & $13.200^{* * *}$ & $12.600^{* * *}$ & 5.750 \\
Capital & [d.f] & {$[3]$} & {$[3]$} & {$[3]$} \\
& (p-value) & $(0.004)$ & $(0.006)$ & $(0.125)$ \\
Locational Factors & LR-test & $16.000^{* * *}$ & $12.250^{* *}$ & $11.320^{* *}$ \\
& {$[$ d.f] } & {$[5]$} & {$[5]$} & {$[5]$} \\
& (p-value) & $(0.007)$ & $(0.032)$ & $(0.045)$ \\
\hline
\end{tabular}

Notes: p-values in parentheses; ${ }^{* * *}$ significant at 1 percent level; ${ }^{* *}$ significant at 5 percent level; $*$ significant at 10 percent level 
Table 4: Logit regressions of firm survival

\begin{tabular}{|c|c|c|c|c|}
\hline & & All Firms & $\begin{array}{l}\text { Micro } \\
\text { Firms }\end{array}$ & $\begin{array}{c}\text { Small and } \\
\text { Medium Sized } \\
\text { Firms } \\
\end{array}$ \\
\hline \multicolumn{5}{|c|}{ Growth Orientation } \\
\hline $\begin{array}{l}\text { General Growth } \\
\text { Motivation }\end{array}$ & Growth Ambitions & $\begin{array}{c}1.5357^{* * *} \\
(0.001)\end{array}$ & $\begin{array}{c}1.5971^{* * *} \\
(0.000)\end{array}$ & $\begin{array}{l}0.2831 \\
(0.119)\end{array}$ \\
\hline \multirow{2}{*}{$\begin{array}{l}\text { Market orientation } \\
\text { (base category Local) }\end{array}$} & Main Market Wales & $\begin{array}{l}0.9996 \\
(0.998)\end{array}$ & $\begin{array}{l}0.9522 \\
(0.780)\end{array}$ & $\begin{array}{l}2.6090 \\
(0.166)\end{array}$ \\
\hline & $\begin{array}{c}\text { Main Market UK } \\
\text { wide or international }\end{array}$ & $\begin{array}{l}0.8547 \\
(0.305)\end{array}$ & $\begin{array}{l}0.8801 \\
(0.434)\end{array}$ & $\begin{array}{l}0.9589 \\
(0.937)\end{array}$ \\
\hline \multicolumn{5}{|c|}{ General Human Capital } \\
\hline \multirow{2}{*}{$\begin{array}{c}\text { Age } \\
\text { (base category aged } 35 \\
\text { to } 49 \text { ) }\end{array}$} & Aged under 35 & $\begin{array}{c}0.6827^{* *} \\
(0.015)\end{array}$ & $\begin{array}{l}0.7928 \\
(0.160)\end{array}$ & $\begin{array}{c}0.1287 * * * \\
(0.001)\end{array}$ \\
\hline & Aged 50 and above & $\begin{array}{c}0.7855^{*} \\
(0.056)\end{array}$ & $\begin{array}{c}0.7762^{*} \\
(0.056)\end{array}$ & $\begin{array}{l}0.4017 \\
(0.105)\end{array}$ \\
\hline \multirow{2}{*}{$\begin{array}{l}\text { Educational attainment } \\
\text { (base category } \\
\text { qualifications below } \\
\text { university level) }\end{array}$} & No Formal Education & $\begin{array}{l}0.7885 \\
(0.116)\end{array}$ & $\begin{array}{r}0.7607^{*} \\
(0.082)\end{array}$ & $\begin{array}{l}2.0885 \\
(0.355)\end{array}$ \\
\hline & University Education & $\begin{array}{l}0.9366 \\
(0.621)\end{array}$ & $\begin{array}{l}0.9609 \\
(0.775)\end{array}$ & $\begin{array}{l}1.0735 \\
(0.895)\end{array}$ \\
\hline \multicolumn{5}{|c|}{ Business Ownership Specific Human Capital } \\
\hline \multirow{3}{*}{$\begin{array}{c}\text { Work status prior to } \\
\text { start-up (base category } \\
\text { employed by someone } \\
\text { else) }\end{array}$} & $\begin{array}{l}\text { Education or } \\
\text { Training }\end{array}$ & $\begin{array}{c}1.7542^{* *} \\
(0.015)\end{array}$ & $\begin{array}{c}1.7616^{* *} \\
(0.020)\end{array}$ & $\begin{array}{l}1.1251 \\
(0.900)\end{array}$ \\
\hline & Out of Work & $\begin{array}{c}0.5329 * * \\
(0.020)\end{array}$ & $\begin{array}{l}0.5931^{*} \\
(0.058)\end{array}$ & $\begin{array}{l}0.8694 \\
(0.921)\end{array}$ \\
\hline & Self-Employed & $\begin{array}{l}1.1466 \\
(0.368)\end{array}$ & $\begin{array}{l}1.3170^{*} \\
(0.087)\end{array}$ & $\begin{array}{c}0.2635^{* *} \\
(0.021)\end{array}$ \\
\hline \multicolumn{5}{|c|}{ Locational Factors } \\
\hline \multirow{2}{*}{ Settlement Type } & Urban & $\begin{array}{l}0.7410 * \\
(0.084)\end{array}$ & $\begin{array}{l}0.7799 \\
(0.170)\end{array}$ & $\begin{array}{l}0.2686 \\
(0.128)\end{array}$ \\
\hline & Village & $\begin{array}{l}0.9347 \\
(0.724)\end{array}$ & $\begin{array}{l}0.9844 \\
(0.937) \\
\end{array}$ & $\begin{array}{l}0.2235 \\
(0.123) \\
\end{array}$ \\
\hline $\begin{array}{l}\text { Growth and } \\
\text { development }\end{array}$ & Change in GVA & $\begin{array}{c}4.7827^{* * *} \\
(0.002)\end{array}$ & $\begin{array}{c}3.2934^{* *} \\
(0.025)\end{array}$ & $\begin{array}{c}358.9466^{* *} \\
(0.011)\end{array}$ \\
\hline Labour market & Unemployment rate & $\begin{array}{c}0.9968 * * \\
(0.033)\end{array}$ & $\begin{array}{c}0.9966^{* *} \\
(0.032)\end{array}$ & $\begin{array}{l}0.9956 \\
(0.496)\end{array}$ \\
\hline Industry Density & $\begin{array}{c}\text { LA Industry Location } \\
\text { Quotient }\end{array}$ & $\begin{array}{l}1.0134 \\
(0.874)\end{array}$ & $\begin{array}{l}0.9952 \\
(0.956)\end{array}$ & $\begin{array}{l}1.3342 \\
(0.526)\end{array}$ \\
\hline
\end{tabular}


Table 4 continued

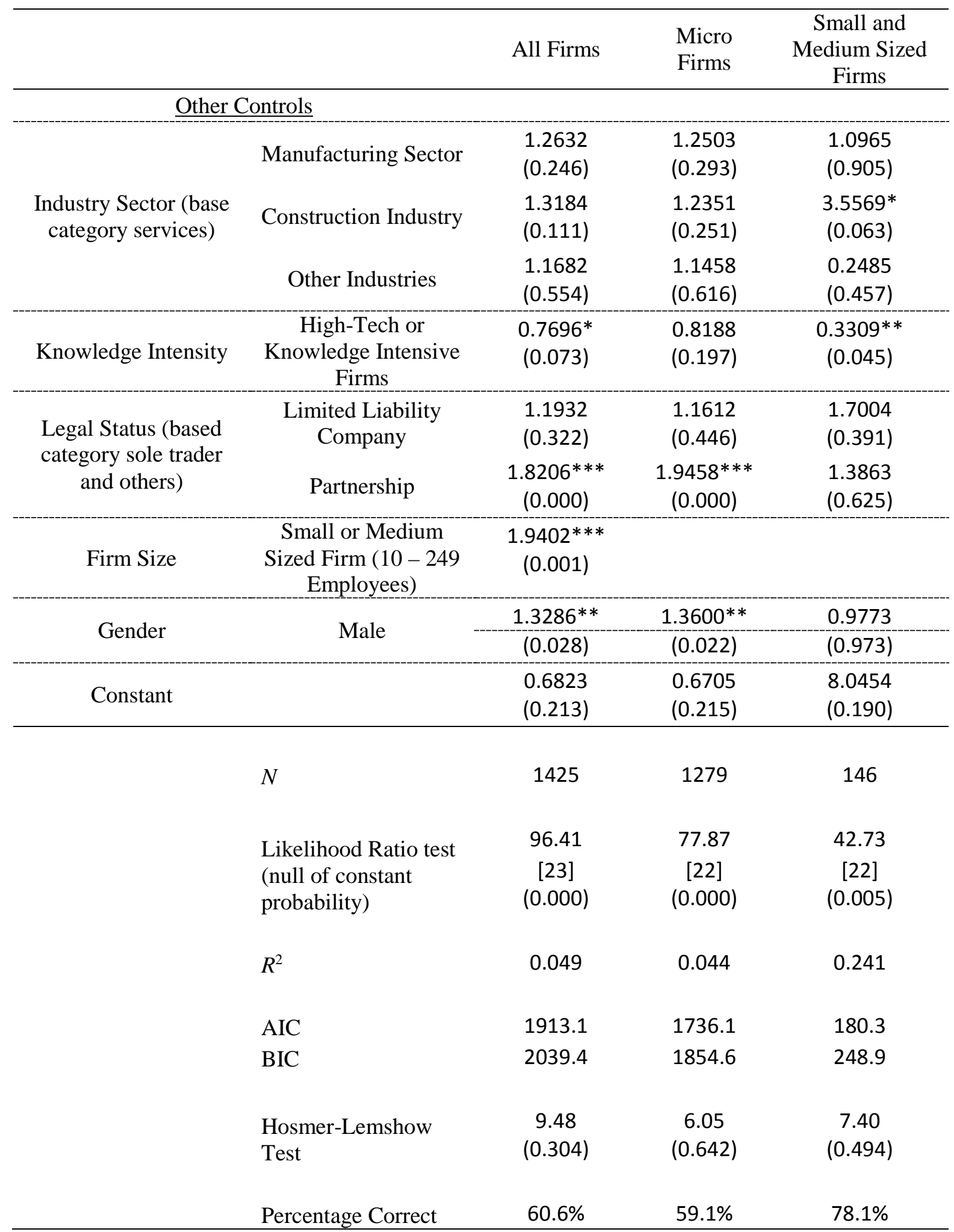

Notes: p-values in parenthesis; ${ }^{* * *}$ significant at 1 percent level; ${ }^{* *}$ significant at 5 percent level; * significant at 10 percent level 
Figure 1: Three factors influencing entrepreneurial exit

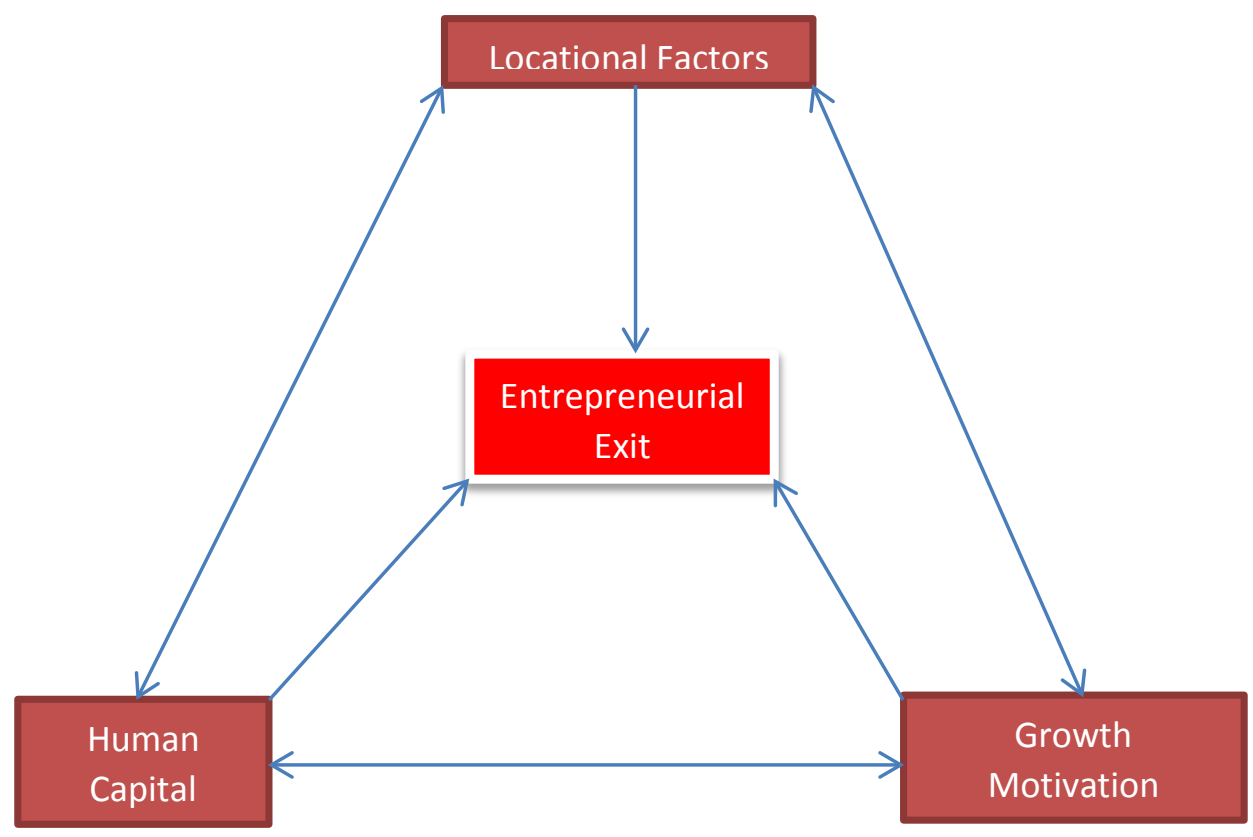


Figure 2: Links between three factors

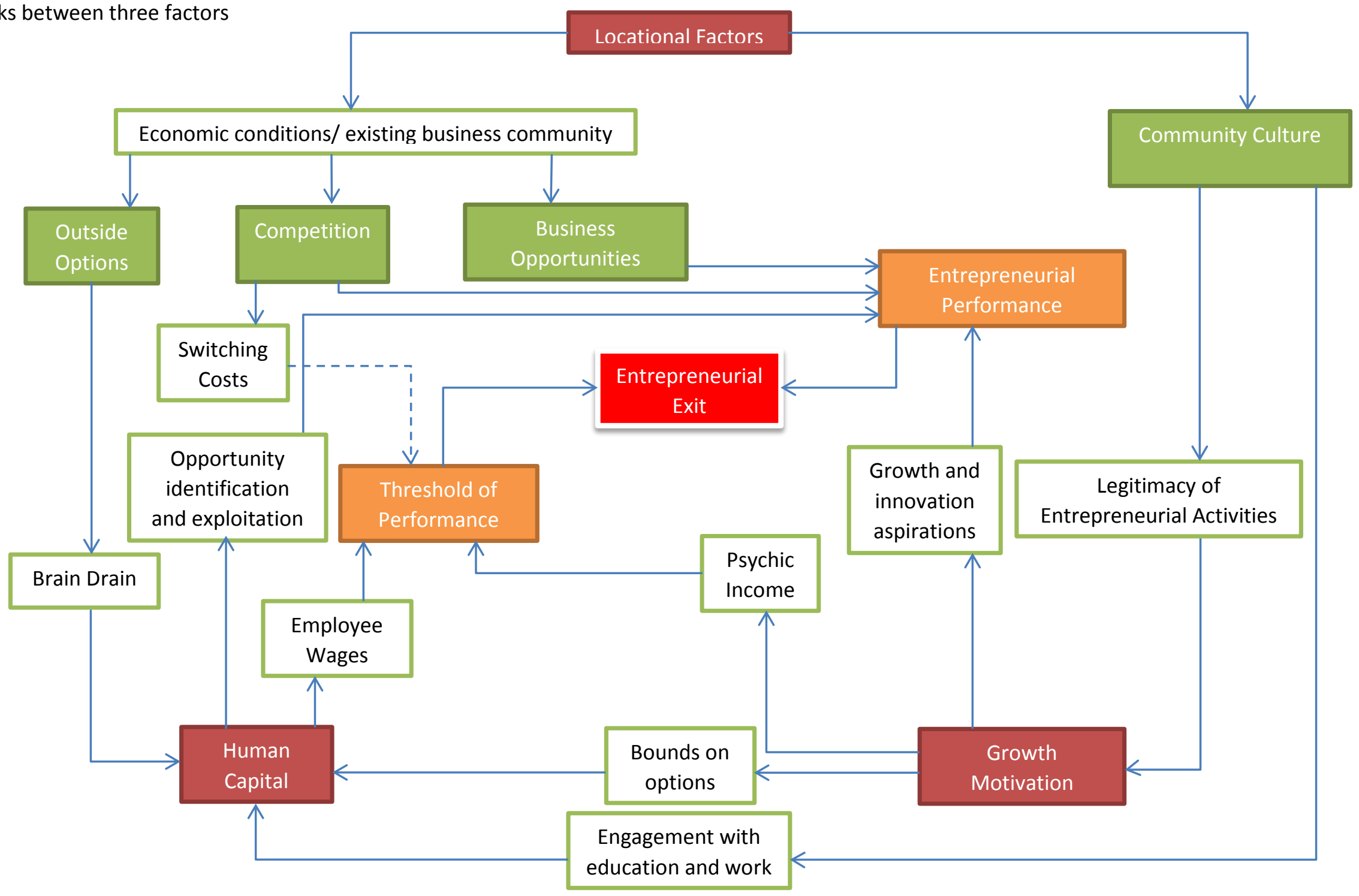


